\title{
From Genotype to Phenotype: Content and Activities of Cytochromes P450 2A6 in Human Liver In Vitro and Predicted In Vivo
}

\author{
Yan Fang, Tong Wang, Yuan-Yuan Guo, Hai-Feng Zhang, Qiang Wen, Yu-Rong Xing, \\ $\mathrm{Na}$ Gao, and Hai-Ling Qiao \\ Institute of Clinical Pharmacology, Zhengzhou University, Zhengzhou, Henan, China Y.F., T.W., Y.-Y.G., H.-F.Z., Q.W., N.G., \\ H.-L.Q.); and Center of Health Examination, The First Affiliated Hospital of Zhengzhou University, Zhengzhou, Henan, China \\ (Y.-R.X.)
}

Received October 9, 2019; accepted December 23, 2019

\begin{abstract}
Unraveling the molecular mechanisms by which genetic variants of cytochrome P450 2A6 lead to different metabolic phenotypes remains a long-standing but important challenge. CYP2A6 is an enzyme involved in the metabolism of several clinical drugs as well as the metabolic activation of carcinogenic nitrosamines. Herein, CYP2A6 genotypes and phenotypes, as indicated by protein content [by liquid chromatography-mass spectrometry (MS)/MS] and metabolic activities [ $\mathrm{V}_{\max }$, clearance (CL)], were determined for 90 human liver samples. We determined the median, range, and interindividual and intraindividual variation of CYP2A6 content and activity at the microsomal, liver tissue, and whole liver level and predicted hepatic in vivo clearance by in vitro-in vivo extrapolation based on CYP2A6-mediated coumarin metabolism by each CYP2A6 genotype. These results reveal how different $C Y P 2 A 6$ genotypes yield different phenotypic traits in protein content and enzyme activity. For relative $\mathrm{V}_{\max }, \mathrm{CL}$, and protein content, the intraindividual percentage coefficients of variation (ICVs) were $41.0 \%(18.8 \%-125.1 \%)$, $28.5 \%(2.39 \%-133.5 \%)$, and $27.8 \%$ (2.68\%-88.0\%), respectively. The high ICVs implied large intraindividual variation at different levels, sometimes in a genotype-dependent manner.
\end{abstract}

Intergenotype analysis revealed that the CYP2A6*4 allele demonstrated the most obvious effect on phenotypic outcomes, both in protein content and in metabolic activity. Indeed, decreased CYP2A6 protein content with the CYP2A6*4 genotype might explain the decreased metabolic activity from the molecular to the organismal level. These findings may allow useful predictions for CYP2A6-mediated drug metabolism on an individual patient basis in accord with the goal of achieving personalized medicine.

\section{SIGNIFICANCE STATEMENT}

We provide the median, range, and interindividual and intraindividual variation in CYP2A6 content at the microsomal, liver tissue, and whole liver level by liquid chromatography-mass spectrometry (MS)/MS as well as activities at the protein, microsomal, liver tissue, and whole liver level both in vitro and at the organismal level based on CYP2A6-mediated coumarin metabolism with each CYP2A6 genotype, thereby allowing us to elucidate how different CYP2A6 genotypes yield differing phenotypic traits (protein content and enzyme activity), facilitating the development of personalized medicine.

\section{Introduction}

A recent study (Tennessen et al., 2012) yielding the sequence of 15,585 human protein-coding genes showed that $2.3 \%$ of the 13,595 single nucleotide variants involving $\sim 313$ genes were predicted to impact protein function. Cytochrome P450 enzymes are characterized by abundant gene polymorphisms and great interindividual variations in drugmetabolizing activity (Zanger and Schwab, 2013). Our previous studies carried out with human liver samples derived from both individuals who were normal or had hepatocellular carcinoma indicated that various genetic variants of CYP450

This work was supported by the National Natural Science Foundation of China [Grants 81473279, 81673507, 8187 2931, and U1804169].

https://doi.org/10.1124/jpet.119.263152.

S This article has supplemental material available at jpet.aspetjournals.org.
(Gao et al., 2016b; Fang et al., 2018a,b) combined with other factors, including CYP450 reductase (Tian et al., 2016; Fang et al., 2018b) and CYPb5 (Zhang et al., 2015a), generated significant variation in metabolic phenotypes (Zhang et al., 2016; Gao et al., 2017c).

More importantly, differences in CYP activity (Gao et al., 2016a; Zhou et al., 2016) are associated with increased risk for diseases like hepatofibrosis (Gao et al., 2017b) and hepatocarcinogenesis (Gao et al., 2018a,b). Thus, studies on CYP genotype-phenotype associations may have important disease implications. However, with regard to metabolic phenotypes for CYPs, research in this area has focused primarily on the effect of CYP genetic variants on enzyme-catalyzed drug metabolism in vitro (Palma et al., 2010; Mürdter et al., 2012; Dai et al., 2014; Werk and Cascorbi, 2014) or on drug clearance in vivo (Mega et al., 2009; Zordoky and El-Kadi, 2010; Zhu

ABBREVIATIONS: BW, body weight; CL, clearance; HLM, human liver microsome; ICV, intraindividual percentage coefficient of variation; LC, liquid chromatography; LW, liver weight; MPPGL, microsomal protein per gram of liver; MS, mass spectrometry. 
et al., 2011; Shuker et al., 2016). It has long been known that genetic effects on physiologic phenotypes often depend on the cellular and environmental context, such as culture media, cell type, or tissue. For this reason, a more comprehensive process for CYP genotype-phenotype association is needed.

In the past several years, CYP2A6 has gained importance in numerous studies on the more than 45 known allelic variants (http://www.imm.ki.se/CYPalleles/cyp2a6.htm) and their roles in the metabolism of coumarin and a number of pharmaceuticals. Along with these pharmaceuticals, toxins and procarcinogens, such as aflatoxin B1 and tobacco-specific nitrosamines, may exhibit differences in blood concentration and duration of effect as a result of $C Y P 2 A 6$ polymorphisms (Sadeque et al., 1997; White et al., 2001; Xu et al., 2002) that are metabolically activated by CYP2A6. Development of a comprehensive genotype-phenotype model for CYP2A6 has the potential to improve our understanding of phenotypic variation and enhance the prediction of clinical outcomes for drugs metabolized by this cytochrome P450.

Clinically, studies on CYP2A6 genotype-phenotype associations may have important clinical implications because of CYP2A6's major role in the metabolism of nicotine. However, studies on CYP2A6 genotypes determined in vitro (Fukami et al., 2005; Wang et al., 2006) (e.g., by site-directed mutagenesis and liver microsomes) and/or in vivo (e.g., by phenotyping using substrates) are not always consistent. Take $C Y P 2 A 6^{*} 1 B$ as example: It was characterized with either elevated catalytic activity (Yoshida et al., 2003; Wang et al., 2006) or normal activity (Ujjin et al., 2002; Peamkrasatam et al., 2006; Wang et al., 2011), making it difficult to determine the genotypephenotype association and predict phenotypic outcomes.

One recent report focused on the CYP2A6 genotypephenotype correlation and showed large interindividual variation in phenotypes (Tanner et al., 2017). Unfortunately, insufficient background information for more than half of the donors made accurate and rigorous evaluation of the genotype-to-phenotype association difficult. Moreover, phenotypes including protein content and activity measured in that study were only determined at one level in vitro. The extrapolation from phenotype in vitro to phenotype in vivo is complex and may involve multiple intermediates. Simple genotype-tophenotype prediction may not be sufficient to accurately determine the phenotype. As a result, efforts to identify the influential intermediate steps in the process from genotype to ultimate phenotype for CYP2A6 are still an urgent need.

With regard to the characterization of CYP2A6 phenotypes, as mentioned in a previous study (Gao et al., 2017a), they can be divided into content phenotypes and metabolic phenotypes, as evidenced by CYP2A6 protein expression and activity from the molecular level to the cellular level and then to organismal level.

We generated a genotype-phenotype model for CYP2A6 based on three gene polymorphisms of CYP2A6 $\left(C Y P 2 A 6^{*} 1 B\right.$, $* 4$, and $* 9$ ) with frequencies greater than $1 \%$ in Chinese subjects. We determined protein expression and metabolic activity from the molecular to the cellular (microsomal, liver tissue, and liver) and organismal level and presented the intraindividual and interindividual variation in metabolic activity for CYP2A6 with different genotypes. Consideration of differences in enzyme activity at the molecular level and the effect on clearance at the organismal level may provide insight into how CYP2A6 molecular genetic variation influences phenotypic variation.

\section{Material and Methods}

\section{Human Liver Samples}

Normal human liver tissues were obtained from 90 Chinese patients undergoing liver surgical resection at Henan Provincial People's Hospital or Henan Provincial Tumor Hospital during 2012 and 2014. This research was performed in accordance with the Declaration of Helsinki. All experiments were approved by the Medical Ethics Committee of Zhengzhou University, and written informed consent was obtained from all patients. All liver samples were obtained from patients who were undergoing hepatic surgery and free of infectious disease, with medical diagnoses mostly of cavernous hemangioma of liver (61 cases); a few had metastatic cancers (seven cases), cholelithiasis (eight cases), gallbladder cancer (four cases), hepatic cholangiocarcinoma (six cases), or hepatocellular carcinoma (four cases). Detailed demographic information for the liver samples are presented in Supplemental Table 1. For patients who were tumor-bearing, normal liver samples were obtained $2 \mathrm{~cm}$ distant from the tumor tissue. Liver function tests, histopathological analysis, and imaging by ultrasonography or computed tomography were used to confirm that only liver tissue with normal liver function and normal histologic appearance was collected. Liver samples were frozen immediately after removal and stored in liquid nitrogen until use. There was no history of exposure to known CYP-inducing or CYP-inhibiting agents, and only routine anesthetics were used with the patients. Detailed donor characteristics of the human liver samples and human liver microsomes (HLMs) and the method of preparation by differential centrifugation are described in a previous study (Zhang et al., 2015b). Total HLM protein concentration was measured by the Bradford method (Bradford, 1976).

\section{Genotyping of CYP2A6}

Genomic DNA was isolated from human liver tissues using a genomic DNA purification kit (Beijing ComWin Biotech Co., Ltd., China). A twostep polymerase chain reaction method (Oscarson et al., 1999) was used to detect $C Y P 2 A 6^{*} 1 B$ and $C Y P 2 A 6^{*} 4$. Another single nucleotide polymorphism $C Y P 2 A 6 * 9$ (rs28399433) was genotyped by polymerase chain reaction sequencing. Genotyping errors were detected by regenotyping with a subsample, and reproducibility was routinely greater than $99 \%$.

\section{Quantification of CYP2A6 Protein}

Protein quantification of CYP2A6 was performed by nano-liquid chromatography (LC)-mass spectrometry (MS)/MS as previously reported (Zhang et al., 2016). A QconCAT protein consisting of 57 stable isotope-labeled peptides from 21 drug-metabolizing enzymes (including CYP2A6) in which two or three peptides were selected for each targeted protein was employed to quantify these proteins in HLMs (Li et al., 2015). The concentration of CYP2A6 protein was determined by nano-LC-multiple reaction monitoring MS using an easy nano-LC (Thermo Fisher Scientific Inc., Waltham, MA) coupled to a TSQVantage Triple Quadrupole mass spectrometer (Thermo Fisher Scientific Inc.).

\section{Determination of Phenotype at Different Levels}

Molecular phenotype is defined as protein content (Content_. $)$ and activity $\left[\mathrm{V}_{\text {max-P }}\right.$, clearance $\left.(\mathrm{CL})_{-\mathrm{P}}\right]$ at the protein level. Cellular phenotype can be divided into microsomal, tissue, and organ levels; accordingly, protein expression at the cellular level in the liver is defined as Content $_{-\mathrm{M}}$, Content $\mathrm{L}_{\mathrm{LT}}$, and Content $\mathrm{L}_{\mathrm{L}}$, and activity is defined as $\mathrm{V}_{\text {max-M }}, \mathrm{V}_{\text {max-LT}}$, and $\mathrm{V}_{\text {max-L }}$ and $\mathrm{CL}_{-\mathrm{M}}, \mathrm{CL}_{-\mathrm{LT}}$, and $\mathrm{CL}_{-\mathrm{L}}$, respectively. For organismal phenotype, this refers to drug clearance from the body at the whole organism level (in vivo).

Microsomal Phenotype. The subcellular phenotype, termed the microsomal phenotype, is defined as protein content $\left(\mathrm{CYP}_{-\mathrm{M}}\right), \mathrm{V}_{\max }$ $\left(\mathrm{V}_{\text {max-M }}\right)$, and clearance $\left(\mathrm{CL}_{-\mathrm{M}}\right) . \mathrm{V}_{\text {max-M }}$ and $\mathrm{CL}_{-\mathrm{M}}$ were determined by measuring the rate of coumarin 7-hydroxylation by high-performance liquid chromatography with eight coumarin concentrations $(0.156-20$ $\mu \mathrm{M})$ according to a previously described method (Zhang et al., 2016). 
Incubation mixtures contained HLMs, $100 \mathrm{mM}$ phosphate buffer $(\mathrm{pH}$ 7.4) with $1 \mathrm{mM} \mathrm{NADPH}$, and substrate. Optimal protein concentration was $0.3 \mathrm{mg} / \mathrm{ml}$ protein, and incubation time was 30 minutes. Perchloric acid $(10 \mu \mathrm{l})$ was added to terminate the reaction. The metabolite was identified by high-performance LC-UV. All experiments included two replicates. The Michaelis-Menten constant $\left(\mathrm{K}_{\mathrm{m}}\right)$ and maximum reaction rate $\left(\mathrm{V}_{\max -\mathrm{M}}\right)$ of CYP2A6 were determined by nonlinear regression analysis using GraphPad Prism 6.0, and $\mathrm{CL}_{-\mathrm{M}}$ was calculated based on the ratio of $\mathrm{V}_{\text {max-M }}$ to $\mathrm{K}_{\mathrm{m}}$.

$$
C L_{-M}=V_{\max -M} / K_{m}
$$

Molecular Phenotype. The metabolic phenotype at the molecular level is defined as $\mathrm{V}_{\text {max }}\left(\mathrm{V}_{\text {max }-\mathrm{P}}\right)$ and clearance $\left(\mathrm{CL}_{-\mathrm{P}}\right)$ of drug per picomole of CYP2A6. The $\mathrm{V}_{\text {max-P }}$ and $\mathrm{CL}_{-\mathrm{P}}$ for each individual were obtained by dividing each individual microsomal phenotype parameter by the corresponding individual CYP2A6 protein content (Content-M).

$$
C L_{-P}=C L_{-M} / \text { Content }_{-M}
$$

Tissue Phenotype. The tissue phenotype is defined as protein content (Content-LT), $\mathrm{V}_{\max }\left(\mathrm{V}_{\max -\mathrm{LT}}\right)$, and clearance $\left(\mathrm{CL}_{-\mathrm{LT}}\right)$. The Content $_{-\mathrm{LT}}, \mathrm{V}_{\mathrm{max}-\mathrm{LT}}$, and $\mathrm{CL}_{-\mathrm{LT}}$ for each individual were obtained by multiplying each individual microsomal phenotype parameter (Content ${ }_{-\mathrm{M}}, \mathrm{V}_{\text {max-M }}$, and $\mathrm{CL}_{-\mathrm{M}}$ ) by the corresponding individual microsomal protein per gram of liver (MPPGL). MPPGL is the microsomal protein per gram of liver and determined as previously reported (Zhang et al., 2015b). The mean MPPGL value was 42.0 $(9.9-127.9) \mathrm{mg} / \mathrm{g}$ in this cohort of 90 liver samples.

$$
C L_{-L T}=C L_{-M} \times M P P G L
$$

Organ Phenotype. The organ phenotype is defined as content (Content-L $), \mathrm{V}_{\max }\left(\mathrm{V}_{\max -\mathrm{L}}\right)$, and clearance $\left(\mathrm{CL}_{-\mathrm{L}}\right)$ in liver. Content- $\mathrm{L}$, $\mathrm{V}_{\text {max-L }}$, and $\mathrm{CL}_{-\mathrm{L}}$ were obtained by multiplying each individual liver weight (LW)/body weight (BW) by the individual tissue phenotype parameter, also known as Content -LT, $_{\text {, }} \mathrm{V}_{\text {max-LT}}$, and $\mathrm{CL}_{-\mathrm{LT}}$, respectively. Detailed values of LW and BW were previously reported (Gao et al., 2017a). BW is the actual body weight for each individual, and LW is the liver weight, which is calculated by multiplying the liver volume $(\mathrm{LV})$ by the liver density, wherein $\mathrm{LV}(\mathrm{ml})=12.5 \times \mathrm{BW}(\mathrm{kg})+$ 536.4 (Wang et al., 2008), and the liver density is $1.001 \mathrm{~g} / \mathrm{ml}$ (Yuan et al., 2008). The mean LW/BW value was $21.2(18.4-30.4) \mathrm{g} / \mathrm{kg}$ in this cohort of 90 liver samples.

Organismal Phenotype. The organismal phenotype is defined as clearance $\left(\mathrm{CL}_{-\mathrm{H}}\right)$ in vivo. According to our previous report, the BiasCorrected Conventional in vitro-in vivo extrapolation method (Gao et al., 2016a, 2017a) was adopted for extrapolating the $\mathrm{CL}_{-\mathrm{H}}$ for different genotypes on the basis of $\mathrm{Q}_{\mathrm{H}}, \mathrm{f}_{\mathrm{u}, \mathrm{p}}$, and $\mathrm{R}_{\mathrm{B}}$. $\mathrm{C}_{\mathrm{O}}$, the cardiac output $\left(\mathrm{C}_{\mathrm{O}}\right)$, determined based on age and gender, was $5.45(4.92-6.65)$ $1 / \mathrm{min}$. $\mathrm{Q}_{\mathrm{H}}$, the hepatic blood flow, determined as $24.5 \%$ of the $\mathrm{C}_{\mathrm{O}}$ (Barter et al., 2013), was 1334.9 (1205.4-1629.3) $\mathrm{ml} / \mathrm{min}$. The plasma unbound fraction, $\mathrm{f}_{\mathrm{u}, \mathrm{p}}$, determined as 0.055 for coumarin and $\mathrm{R}_{\mathrm{B}}$, ratio of the drug concentration in blood to plasma, and as 1 for coumarin, was obtained from our previous study (Gao et al., 2016a). Detailed data and the computing method for $\mathrm{Q}_{\mathrm{H}}, \mathrm{f}_{\mathrm{u}, \mathrm{p}}$, and $\mathrm{R}_{\mathrm{B}}$ were reported in our previous studies (Zhang et al., 2015b; Gao et al., 2016a). The clearance for CYP2A6 in vivo $\left(\mathrm{CL}_{-\mathrm{H}}\right)$ was calculated using the wellstirred model:

$$
\mathrm{CL}_{-\mathrm{H}}=\left(\mathrm{Q}_{\mathrm{H}} \times C L_{-L} \times \mathrm{f}_{\mathrm{u}, \mathrm{p}} / \mathrm{R}_{\mathrm{B}}\right) /\left(\mathrm{Q}_{\mathrm{H}}+C L_{-L} \times \mathrm{f}_{\mathrm{u}, \mathrm{p}} / \mathrm{R}_{\mathrm{B}}\right)
$$

The average fold error (AFE) was introduced to assess the overall accuracy of prediction, which was calculated as follows:

$$
\mathrm{AFE}=10^{\frac{1}{\mathrm{~N}} \sum \log (\text { predicted mean } / \text { observed overall mean })}
$$

The individual fold error (IFE) was introduced to evaluate the individual accuracy, which was calculated as:

$$
\mathrm{IFE}=10^{\frac{1}{\mathrm{~N}} \sum \log (\text { predicted individual value/observed overall mean })}
$$

$\mathrm{N}$ refers to the number of separate reports in the literature concerning coumarin intravenous clearance.

The definitions and corresponding units for parameters at each level were listed in Table 1.

\section{Intraindividual Variation of CYP2A6 at Different Levels}

To make CYP2A6 phenotypes at different levels comparable, relative $V_{\max }\left(R_{-V_{\max }}\right)$, relative $C L\left(R_{-C L}\right)$, and relative Content $\left(\mathrm{R}_{\text {-Content }}\right)$ were computed. For one specific level, $\mathrm{R}_{-\mathrm{Vmax}}, \mathrm{R}_{-\mathrm{CL}}$, and $\mathrm{R}_{\text {-Content }}$ were calculated as the individual $\mathrm{V}_{\max }, \mathrm{CL}$, and Content divided by the median for that level. Variation in $R_{-V \max }, R_{-C L}$, and $R_{\text {-Content }}$ among different levels for each person was expressed as the intraindividual percentage coefficient of variation (ICV).

Relative phenotypes $\left(\mathrm{R}_{\text {-Vmax }}, \mathrm{R}_{-\mathrm{CL}}\right.$ and $\left.\mathrm{R}_{\text {-Content }}\right)=$ (individual value) /(median)

ICV for relative phenotypes $=($ standard deviation $) /($ average value $)$

For one specific relative phenotype $\left(R_{-V \max }, R_{-C L}\right.$ or $\left.R_{-C o n t e n t}\right)$, the ICV was calculated as the S.D. divided by the corresponding average value of the relative phenotype among different levels.

To compare the variation trend of $\mathrm{V}_{\max }$ and CL from the molecular to the organismal level, the percentage rank change of individual CYP2A6 phenotypes was developed. Ninety samples were ranked in ascending order according to the value of each metabolic phenotype parameter: $\mathrm{V}_{\text {max-P }}, \mathrm{V}_{\text {max-M }}, \mathrm{V}_{\text {max-LT }}, \mathrm{V}_{\text {max }-\mathrm{L}}, \mathrm{CL}_{-\mathrm{P}}, \mathrm{CL}_{-\mathrm{M}}, \mathrm{CL}_{-\mathrm{LT}}, \mathrm{CL}_{-\mathrm{L}}$, and $\mathrm{CL}_{-\mathrm{H}}$. The rank change for each individual was determined by comparison with phenotype at the molecular level $\left(\mathrm{V}_{\text {max-P }}\right.$ or $\left.\mathrm{CL}_{-\mathrm{P}}\right)$, calculation of the absolute difference value between the rank of $\mathrm{V}_{\max }$ or CL at different levels $\left(\mathrm{V}_{\text {max-M }}, \mathrm{V}_{\text {max-LT }}, \mathrm{V}_{\text {max-L }}\right.$, or $\mathrm{CL}_{-\mathrm{M}}, \mathrm{CL}_{-\mathrm{LT}}, \mathrm{CL}_{-\mathrm{L}}$, and $\mathrm{CL}_{-\mathrm{H}}$ ), and the rank of corresponding $\mathrm{V}_{\text {max-P }}$ or $\mathrm{CL}_{-\mathrm{P}}$. The percentage of rank change was computed for the sum of the 90 samples divided by the rank change absolute value of each individual. For CYP2A6 content, content phenotype at the molecular level could not be obtained, and so analysis of its rank change could not be determined.

\section{Intergenotype Variation of CYP2A6 at Different Levels}

$\mathrm{V}_{\text {max-P}}, \mathrm{V}_{\text {max-M }}, \mathrm{V}_{\text {max-LT }}, \mathrm{V}_{\text {max-L}}$, Content-M, Content-LT, Content-L, $\mathrm{CL}_{-\mathrm{P}}, \mathrm{CL}_{-\mathrm{M}}, \mathrm{CL}_{-\mathrm{LT}}, \mathrm{CL}_{-\mathrm{L}}$, and $\mathrm{CL}_{-\mathrm{H}}$ were sorted by CYP2A6 genotype. As compared with wild type, fold changes of genotype were calculated by dividing the absolute value of the median for the phenotype by the absolute value of median for the corresponding wild type. The fold change for all phenotypes with wild type was defined as one.

\section{Statistical Analysis}

Statistical analysis was performed using SPSS 22.0 software (SPSS Inc., Chicago, IL). Kolmogorov-Smirnov and Shapiro-Wilk tests were introduced to assess the normality of the data distribution. One-way ANOVA and Bonferroni tests were used for the comparison of relative phenotype potency. Since most data sets of phenotypes, including kinetic parameters and protein content, were not normally distributed, nonparametric methods were generally used. Mann-Whitney U and Kruskal-Wallis $\mathrm{H}$ tests were used for pairwise comparison and multiple pairwise comparisons of phenotypes with different genetic polymorphisms. Nonparametric Spearman rank correlation analysis was conducted to calculate the correlation coefficient ( $r$ ) among different phenotypes. $P<0.05$ (two-tailed) was considered statistically significant. Graphs were generated using Graph Pad Prism software version 6.02. Both the genotyping and phenotyping tests were derived from three separate and independent replicates to obtain 
TABLE 1

Definitions of phenotypes for CYP2A6 at different levels

Molecular level, or phenotype at the protein level, $\mathrm{V}_{\text {max-P }}$ ( $\mathrm{pmol} / \mathrm{min}$ per picomole), $\mathrm{CL}_{-\mathrm{P}}\left(\mu \mathrm{l} / \mathrm{min}\right.$ per picomole). Subcellular level, or phenotype at microsomal level, $\mathrm{V}_{\text {max-M }}$ (pmol/min per milligram), $\mathrm{CL}_{-\mathrm{M}}\left(\mu \mathrm{l} / \mathrm{min}\right.$ per milligram), Content-M $(\mathrm{pmol} / \mathrm{mg})$. Tissue level, or phenotype at liver tissue level, $\mathrm{V}_{\max -\mathrm{LT}}\left(\mathrm{pmol} / \mathrm{min} \mathrm{per}\right.$ gram), $\mathrm{CL}_{-\mathrm{LT}}(\mu \mathrm{l} / \mathrm{min} \mathrm{per}$

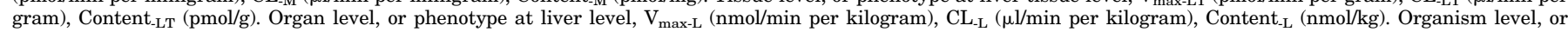
phenotype (clearance) at in vivo level, $\mathrm{CL}_{-\mathrm{H}}(\mathrm{ml} / \mathrm{min})$.

\begin{tabular}{|c|c|c|c|c|c|c|}
\hline \multirow{2}{*}{ Level } & \multicolumn{2}{|r|}{$\mathrm{V}_{\max }$} & \multicolumn{2}{|r|}{$\mathrm{CL}_{\text {int }}$} & \multicolumn{2}{|c|}{ Content } \\
\hline & Def & Units & Def & Units & Def & Units \\
\hline Molecular (protein) & $V_{\text {max-P }}$ & $\mathrm{mol} / \mathrm{min}$ per picomole & $\mathrm{CL}_{-\mathrm{P}}$ & $\mu \mathrm{l} / \mathrm{min}$ per picomole & _ & {[} \\
\hline Subcellular (microsomal) & $V_{\max -M}$ & $\mathrm{~mol} / \mathrm{min}$ per milligram & $\mathrm{CL}_{-\mathrm{M}}$ & $\mu \mathrm{l} / \mathrm{min}$ per milligram & Content $_{-M}$ & $\mathrm{pmol} / \mathrm{mg}$ \\
\hline Tissue (liver tissue) & $\mathrm{V}_{\max -\mathrm{LT}}$ & $\mathrm{mol} / \mathrm{min}$ per gram & $\mathrm{CL}_{-\mathrm{LT}}$ & $\mu 1 /$ min per gram & Content $_{\text {-LT }}$ & $\mathrm{pmol} / \mathrm{g}$ \\
\hline Organ (liver) & $\mathrm{V}_{\max -\mathrm{L}}$ & $\mathrm{mol} / \mathrm{min}$ per kilogram & $\mathrm{CL}_{-\mathrm{L}}$ & $\mu \mathrm{l} / \mathrm{min}$ per kilogram & Content $_{-\mathrm{L}}$ & $\mathrm{nmol} / \mathrm{kg}$ \\
\hline Organism (in vivo) & $\underline{\max -\mathrm{L}}$ & - & $\mathrm{CL}_{-\mathrm{H}}$ & $\mathrm{ml} / \mathrm{min}$ & $-\mathrm{L}$ & 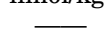 \\
\hline
\end{tabular}

def, definitions.

an accurate value. Experimental results were averaged to obtain a single value for that experimental series.

\section{Results}

\section{Genotype of CYP2A6}

The three most common genetic variants with an allele frequency of more than $1 \%$ in the Chinese population were analyzed for a total of 90 samples. The allele $C Y P 2 A 6^{*} 1 B$ has a gene conversion located in the $3^{\prime}$-untranslated region, with the frequency of the wild-type, heterozygous, and homozygous genotypes being $12.22 \%, 56.67 \%$, and $17.78 \%$, respectively. $C Y P 2 A 6^{*} 4$ is a $C Y P 2 A 6$ gene-deletion variant, with the frequency of the wild type and heterozygotes being $86.67 \%$ and $13.33 \%$, respectively, and with no homozygous genotype detected. The CYP2A $6 * 9(-48 \mathrm{~T}>\mathrm{G})$ is located in the TATA box, with the frequency of the wild-type, heterozygous, and homozygous genotypes being $51.11 \%, 32.22 \%$, and $3.33 \%$, respectively.

\section{Phenotype of CYP2A6}

Phenotypes at Different Levels. Substantial interindividual variations in the metabolic phenotypes $\left(\mathrm{V}_{\max }, \mathrm{CL}\right)$ and protein phenotypes (Content) for CYP2A6 from the molecular to cellular level and then to organismal levels are depicted in Table 2, with the greatest difference demonstrated in CL (454fold) at microsomal level, $144.8(1.20 \sim 544.7) \mu \mathrm{l} / \mathrm{min}$ per milligram. The CL phenotype exhibited the most remarkable variations, followed by $\mathrm{V}_{\max }$, and CYP2A6 content was relatively smaller at most levels. Variations of $\mathrm{V}_{\max }$ showed an increased trend from molecular (63.8-fold) to the tissue level (247-fold) and then to the organ level (134-fold).

To make CYP2A6 phenotypes at different levels comparable, relative $\mathrm{V}_{\max }\left(\mathrm{R}_{-\mathrm{V} \max }\right), \mathrm{CL}\left(\mathrm{R}_{-\mathrm{CL}}\right)$, and Content ( $\left.\mathrm{R}_{\text {-Content }}\right)$ were computed. Each level's $\mathrm{R}_{-\mathrm{V}_{\max }}, \mathrm{R}_{-\mathrm{CL}}$, and $\mathrm{R}_{\text {-Content }}$ were calculated as the individual $\mathrm{V}_{\max }, \mathrm{CL}$, and Content divided by the median for that level. To sort each level's relative phenotypes in a strong-to-weak sequence, we evaluated the relative potencies at each level $\left(\mathrm{R}_{\text {-Vmax }}, \mathrm{R}_{-\mathrm{CL}}\right.$, and $\left.\mathrm{R}_{\text {-Content }}\right)$ in 90 samples. It is noteworthy that the $R$-Vmax potencies at the organ (liver) level, compared with other levels, were always higher. Analysis for the values of $\mathrm{R}$-vmax of four different levels revealed that the $R$-vmax for the organ level was significantly higher than that of the other three levels (Table 2). For values of $R_{-C L}$ and $R_{\text {-Content }}$, statistically significant differences were not demonstrated among different levels.

Intraindividual Variation among Different Levels. The relative $\mathrm{V}_{\max }\left(\mathrm{R}_{\text {- }} \mathrm{V}_{\max }\right), \mathrm{CL}\left(\mathrm{R}_{\mathrm{CL}_{\mathrm{CL}}}\right)$, and Content ( $\left.\mathrm{R}_{\text {-Content }}\right)$ values for different levels are depicted in Fig. 1. The ICVs of

\section{TABLE 2}

CYP2A6 phenotypes at different levels $(n=90)$

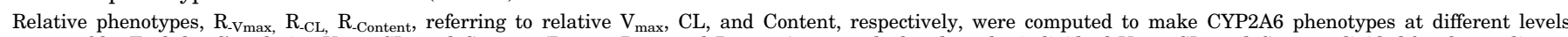
comparable. Each level's relative $V_{\max }$, CL, and Content $\left(R_{-V_{\max }}, R_{-\mathrm{CL}}\right.$, and $\left.\mathrm{R}_{\text {-Content }}\right)$ were calculated as the individual $\mathrm{V}_{\max }$, $C L$, and Content divided by the median of corresponding parameter for that level. Molecular level, or phenotype at the protein level, $\mathrm{V}_{\text {max } \mathrm{P}}\left(\mathrm{pmol} / \mathrm{min}\right.$ per picomole), $\mathrm{CL}_{-\mathrm{P}}(\mu \mathrm{l} / \mathrm{min}$ per picomole). Subcellular level, or phenotype at microsomal level, $\mathrm{V}_{\max -\mathrm{M}}\left(\mathrm{pmol} / \mathrm{min}\right.$ per milligram), $\mathrm{CL}_{-\mathrm{M}}\left(\mu \mathrm{l} / \mathrm{min}\right.$ per milligram), Content-M $(\mathrm{pmol} / \mathrm{mg})$. Tissue level, or phenotype at liver tissue level, $\mathrm{V}_{\text {max-LT }}$ (pmol/min per gram), $\mathrm{CL}_{-\mathrm{LT}}\left(\mu \mathrm{l} / \mathrm{min}\right.$ per gram), Content $\mathrm{LT}_{\mathrm{LT}}(\mathrm{pmol} / \mathrm{g})$. Organ level, or phenotype at liver level, $\mathrm{V}_{\max -\mathrm{L}}\left(\mathrm{nmol} / \mathrm{min}\right.$ per kilogram), $\mathrm{CL}_{-\mathrm{L}}(\mu \mathrm{l} / \mathrm{min}$ per kilogram), Content $_{-\mathrm{L}}(\mathrm{nmol} / \mathrm{kg})$. Organism level, or phenotype (clearance) at in vivo level, $\mathrm{CL}_{-\mathrm{H}}(\mathrm{ml} / \mathrm{min})$.

\begin{tabular}{|c|c|c|c|c|c|c|c|c|c|}
\hline \multirow{2}{*}{ Level } & \multicolumn{3}{|c|}{$\mathrm{V}_{\max }$} & \multicolumn{3}{|c|}{ CL } & \multicolumn{3}{|c|}{ Content } \\
\hline & Range & Ratio & $\mathrm{R}_{-\mathrm{V} \max }$ & Range & Ratio & $\mathrm{R}_{-\mathrm{CL}}$ & Range & Ratio & $\mathrm{R}_{\text {-Content }}$ \\
\hline Molecular (protein) & $\begin{array}{c}\text { M } 19.79 \\
\text { R } 1.08-68.89\end{array}$ & 63.8 & $1.16 \pm 0.71$ & $\begin{array}{c}8.73 \\
0.83-43.89\end{array}$ & 52.9 & $1.19 \pm 0.86$ & - & - & - \\
\hline Subcellular (microsomal) & $\begin{array}{c}\text { M 354.4 } \\
\text { R } 9.47-1430\end{array}$ & 151 & $1.07 \pm 0.78$ & $\begin{array}{c}144.8 \\
1.20-544.7\end{array}$ & 454 & $0.97 \pm 0.43$ & $\begin{array}{c}14.60 \\
1.44-54.89\end{array}$ & 38.1 & $1.22 \pm 0.75$ \\
\hline Tissue (liver tissue) & $\begin{array}{l}\text { M } 12.27 \\
\mathrm{R} \\
0.25-61.74\end{array}$ & 247 & $1.28 \pm 1.14$ & $\begin{array}{c}5.19 \\
0.06-17.03\end{array}$ & 284 & $1.12 \pm 0.68$ & $\begin{array}{c}637.6 \\
71.17-3031\end{array}$ & 42.6 & $1.09 \pm 0.56$ \\
\hline Organ (liver) & $\begin{array}{c}\text { M } 267 \\
\text { R } 6.22-1337\end{array}$ & 214 & $2.08 \pm 1.86^{a, b, c}$ & $\begin{array}{c}109.2 \\
1.36-371.2\end{array}$ & 273 & $1.13 \pm 0.70$ & $\begin{array}{c}893.2 \\
58.43-5497\end{array}$ & 94.1 & $1.14 \pm 0.89$ \\
\hline Organism (in vivo) & $\mathrm{M}-$ & - & - & $\begin{array}{c}287.3 \\
3.87-653.5\end{array}$ & 169 & $1.05 \pm 0.48$ & - & - & - \\
\hline
\end{tabular}

$M$, median; $R$, range.

${ }^{a} P<0.05$ vs. $\mathrm{V}_{\text {max-P }}$ at molecular level.

${ }^{b} P<0.05$ vs. $\mathrm{V}_{\max -\mathrm{M}}$ at microsomal level.

${ }^{c} P<0.05$ vs. $\mathrm{V}_{\max -\mathrm{LT}}$ at tissue level. 
R-Vmax, R-CL, and R-Content within different levels were $41.0 \%$ (18.8\%-125.1\%), 28.5\% (2.39\%-133.5\%), and $27.8 \%$ $(2.68 \%-88.0 \%)$ for 90 cases (Fig. 1A). ICVs with the values $>100 \%, 50 \%-100 \%$, and $<50 \%$ are indicative of high, moderate, and low variation, respectively. In these 90 cases, the number (percentage) of high, moderate, and low ICVs for the values of $\mathrm{R}$-vmax within four levels was 4 (4.44\%), 10 $(11.1 \%)$, and $76(84.4 \%)$; for $\mathrm{R}_{-\mathrm{CL}}$, they were $4(4.44 \%), 24$ (26.7\%), and 62 (68.9\%); and for $\mathrm{R}_{-}{ }_{\text {Content }}$, they were $15(16.7 \%)$ and $75(83.3 \%)$ for moderate and low ICV, respectively, with no high ICV detected. The results indicated surprisingly high intraindividual variation for CYP2A6 phenotypes among different levels. When relative phenotypes were classified by CYP2A6 genotypes, the ICVs of $\mathrm{R}_{-{ }_{\text {Vmax }}}, \mathrm{R}_{-\mathrm{CL}}$, and $\mathrm{R}_{- \text {Content }}$ within different levels varied (Fig. 1, B-D). One notable example was for the $C Y P 2 A 6^{*} 4$ polymorphism, with $\mathrm{R}$-vmax being $39.1 \%(18.8 \%-100.8 \%)$ and $50.0 \%(25.9 \%-125.0 \%)$ and $\mathrm{R}_{-\mathrm{CL}}$ being $26.7 \%(2.39 \%-102.9 \%)$ and $41.6 \%(11.1 \%-133.5 \%)$ for $* 1 / * 1$ and $* 1 / * 4$ genotypes, respectively. For $\mathrm{R}_{\text {-Content, }}$, the genotype-dependent effect was less obvious.

To obtain more detailed information on how the alteration of CYP2A6 phenotypes among different levels originated, values for MPPGL, LW/BW, and $\mathrm{Q}_{\mathrm{H}}$ (hepatic blood flow) were determined for individuals with CYP2A6 genetic differences (Fig. 2). Metabolic phenotypes at the liver tissue level $\left(\mathrm{V}_{\max -\mathrm{LT}}, \mathrm{CL}_{-\mathrm{LT}}\right)$ were obtained by multiplying each individual MPPGL by the corresponding individual $\mathrm{V}_{\max }$ or $\mathrm{CL}$ at the microsomal level. LW/BW and $\mathrm{Q}_{\mathrm{H}}$ were introduced to determine phenotypes at the organ and organismal levels, respectively. However, no significant effect of CYP2A6 genotype was found.

\section{Genotype-Phenotype Association}

No significant effect of demographic factors, including gender, age, smoking status, drinking habit, and medical diagnoses (Supplemental Table 1), on phenotypes was detected (Supplemental Figs. 1-5).

CYP2A6*1B. No significant differences were found for $\mathrm{V}_{\text {max }}$ and CL at different levels among genetically different individuals with respect to $C Y P 2 A 6^{*} 1 B$ polymorphisms, nor was a significant effect on the $K_{m}$ value detected. As for the content of CYP2A6 at different levels, the effect varied, with a minor impact on Content -LT $_{\text {T }}$ and Content -L $_{-}$, as demonstrated by significantly higher Content -LT $_{\text {and Content }}$-L for individuals carrying $C Y P 2 A 6^{*} 1 B / * 1 B$ homozygote as compared with ${ }^{*} 1 A /{ }^{*} 1 B$ heterozygotes; however, there was no significant difference as compared with wild type. It is worth mentioning that strongly significant correlations were charted between $K_{m}$ and $V_{\text {max }}$ at different levels among most of the genetic variants and were dependent upon CYP2A 6 variant. For instance, for $\mathrm{V}_{\text {max }}$ at microsomal level $\left(\mathrm{V}_{\text {max-M }}\right)$, extremely high correlation was detected with $\mathrm{K}_{\mathrm{m}}$ for all $C Y P 2 A 6^{*} 1 B$-related variants (Fig. 3); however, in terms of $\mathrm{V}_{\max }$ at the isoform level $\left(\mathrm{V}_{\max -\mathrm{P}}\right)$, no significant correlation was obtained with $\mathrm{K}_{\mathrm{m}}$ for $C Y P 2 A 6^{*} 1 A / * 1 A$ wild type, and moderate correlation was obtained for $* 1 A / * 1 B$ and $* 1 B / * 1 B$ subjects. The mechanism underlying this observation remained to be determined.

CYP2A6*4. CYP2A $6 * 4$ was significantly associated with decreased $V_{\max }$, and the effect on phenotype at the cellular level was more markedly significant than that at the molecular level. The $\mathrm{V}_{\text {max-P }}$ values of $C Y P 2 A 6^{*} 1 / * 4$ individuals (15.24 pmol/min per picomole) were dramatically lower than *1/*1 (26.45 pmol/min per picomole), and the $\mathrm{V}_{\text {max-M}}, \mathrm{V}_{\text {max-LT}}$, and $\mathrm{V}_{\text {max-L }}$ of $C Y P 2 A 6^{*} 1 / * 4$ individuals were significantly less than a third of $* 1 / * 1$ genotypes (Fig. 4). Subjects carrying CYP2A6*1/*4 genotypes showed lower content-M $(10.62 \mathrm{pmol} / \mathrm{mg})$ and content -LT $_{\text {( }}(370 \mathrm{pmol} / \mathrm{g})$ when compared with content $-\mathrm{M}$ (18.92 pmol/mg) and content-LT $(629 \mathrm{pmol} / \mathrm{g})$ for subjects with $* 1 / * 1$. Observably lower values of content -M $_{\text {and }}$ antent -LT $_{\text {for }}$ $*_{1} / 4$ individuals than those in $* 1 / * 1$ individuals might explain significantly greater lowered $V_{\max -M}$ and $V_{\max -L T}$ in
A
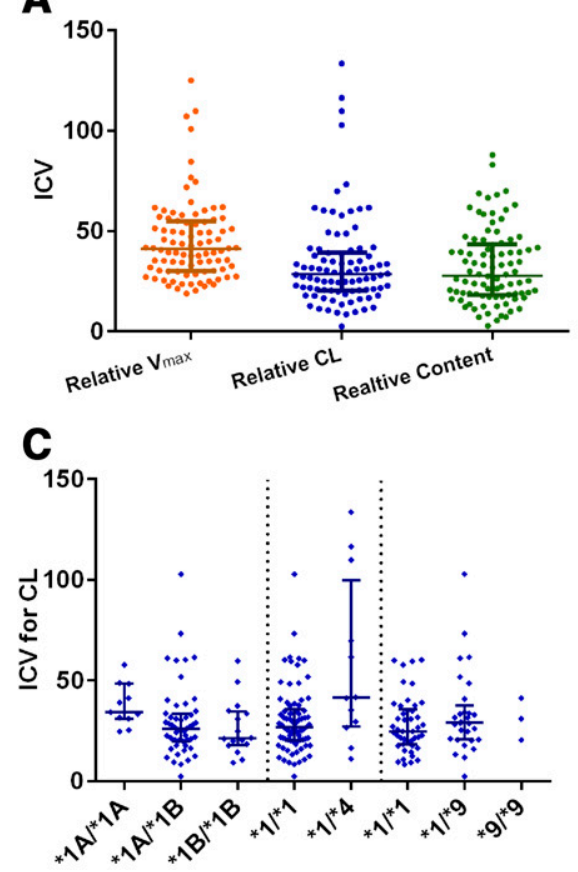

B
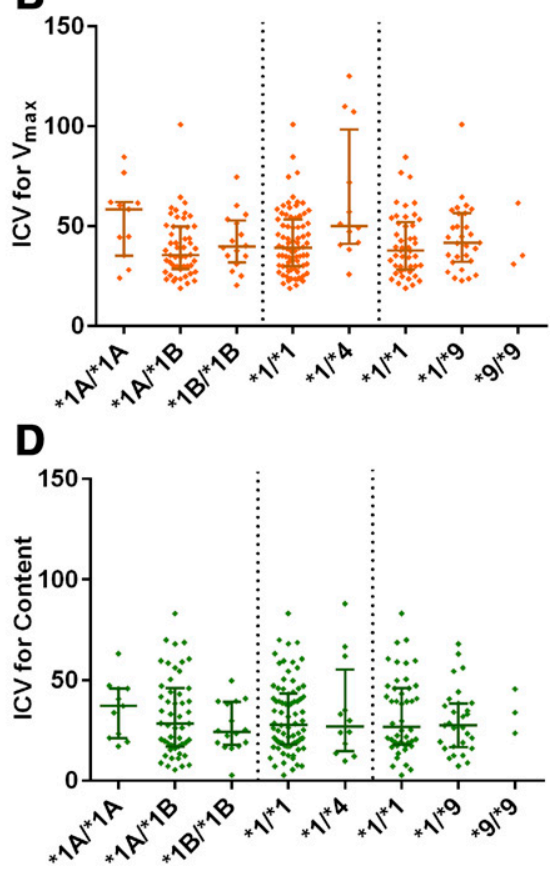

Fig. 1. ICVs of relative $\mathrm{V}_{\max }, \mathrm{CL}$, and Content of CYP2A6 at different levels $(n=90)$. ICVs of relative $\mathrm{V}_{\max }, \mathrm{CL}$, and Content of CYP2A6 for total samples (A) and ICVs of relative $\mathrm{V}_{\max }$ (B), CL (C), and Content (D) sorted by different CYP2A6 genotypes. ICVs were calculated as the S.D. of relative $\mathrm{V}_{\max }$, $\mathrm{CL}$, and Content divided by the corresponding average value for that case. Each level's relative $\mathrm{V}_{\max }, \mathrm{CL}$, and Content were calculated as the individual $\mathrm{V}_{\max }$, $\mathrm{CL}$, and Content divided by the median for that level. Horizontal lines represent medians with the interquartile range. $* 1 A / * 1 A$, $n=11 ; * 1 A / * 1 B, n=51 ; * 1 B / * 1 B, n=16 . * 1 / * 1$, $n=78 ; * 1 * 4, n=12 .{ }^{*} 1 / * 1, n=46 ; * 1 / * 9, n=29$; $* 9 / * 9, n=3$. 

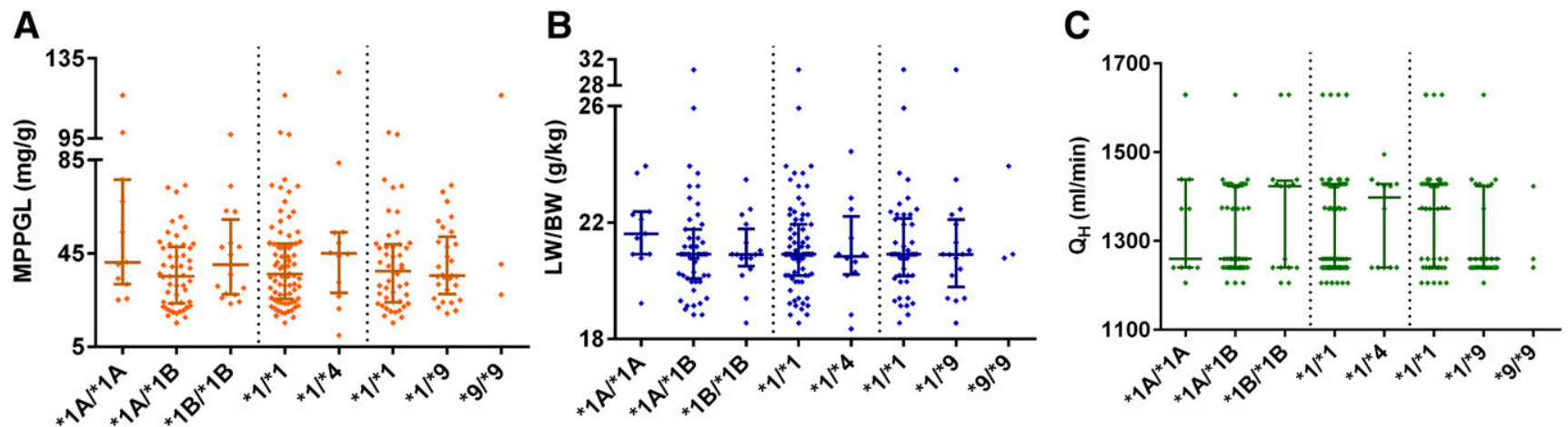

Fig. 2. Effect of CYP2A6 genotypes on MPPGL (A), LW/BW (B), and $\mathrm{Q}_{\mathrm{H}}(\mathrm{C})$. $\mathrm{Q}_{\mathrm{H}}$, hepatic blood flow. Horizontal lines represent medians with the interquartile range. ${ }^{*} 1 A /{ }^{*} 1 A, n=11 ;{ }^{*} 1 A /{ }^{*} 1 B, n=51 ;{ }^{*} 1 B / * 1 B, n=16 .{ }^{*} 1 /{ }^{*} 1, n=78 ; * 1 * 4, n=12 .{ }^{*} 1 /{ }^{*} 1, n=46 ;{ }^{*} 1 / * 9, n=29 ; * 9 / * 9, n=3$.

$* 1 / * 4$ individuals than $* 1 / * 1$ subjects. Consistent with this, we found that the $\mathrm{V}_{\text {max-L }}$ values of $* 1 / * 4$ individuals $(110.2$ $\mathrm{nmol} / \mathrm{min}$ per kilogram) were significantly lower than $* 1 / * 1$ (366.2 $\mathrm{nmol} / \mathrm{min}$ per kilogram) individuals.

It should be stated that individuals with the CYP2A $6^{*} 1$ / $^{*} 4$ genotype showed lower $\mathrm{K}_{\mathrm{m}}$ than those with the $* 1 / * 1$ genotype. No statistical difference was found for $\mathrm{CL}_{-\mathrm{P}}$, which was obtained by dividing each individual $\mathrm{V}_{\text {max-P }}$ by the individual $\mathrm{K}_{\mathrm{m}}$, between the ${ }^{*} 1 /{ }^{*} 1(10.76 \mu \mathrm{l} / \mathrm{min}$ per picomole) and $* 1 / * 4(10.83 \mu \mathrm{l} / \mathrm{min}$ per picomole $)$ genotypes, and this might be due to the simultaneously lowered $V_{\text {max-P }}$ and $K_{m}$ in individuals and the effect on $\mathrm{V}_{\text {max-P }}$ partially counteracting the negative effect on $\mathrm{K}_{\mathrm{m}}$, as evidenced by significant correlation between $\mathrm{K}_{\mathrm{m}}$ and $\mathrm{V}_{\text {max-P }}\left(\mathrm{r}=0.457, P=2.570 \times 10^{-5}\right)$ for $* 1 / * 1$ individuals; however, no such correlation was seen for ${ }^{*} 1 / * 4$ individuals. The $\mathrm{CL}_{-\mathrm{M}}(75.05 \mu \mathrm{l} / \mathrm{min}$ per milligram),
$\mathrm{CL}_{-\mathrm{LT}}\left(3.70 \mathrm{ml} / \mathrm{min}\right.$ per gram), and $\mathrm{CL}_{-\mathrm{L}}(76.97 \mathrm{ml} / \mathrm{min}$ per kilogram) of CYP2A6 for subjects with $* 1 / * 4$ were dramatically lower than those for $* 1 / * 1$ individuals $(150.11 \mu \mathrm{l} / \mathrm{min}$ per milligram, $6.12 \mathrm{ml} / \mathrm{min}$ per gram, and $130.12 \mathrm{ml} / \mathrm{min}$ per kilogram, respectively). This could be due to the simultaneously lowered $\mathrm{V}_{\text {max-P }}, \mathrm{V}_{\text {max-M}}, \mathrm{V}_{\text {max-LT }}, \mathrm{V}_{\text {max }-\mathrm{L}}$, and $\mathrm{K}_{\mathrm{m}}$ in individuals, as evidenced by a significant correlation between $K_{m}$ and $V_{\text {max }}$ at different levels, especially for the extremely strong correlation between $\mathrm{K}_{\mathrm{m}}$ and $\mathrm{V}_{\text {max }-\mathrm{M}}\left(\mathrm{r}=0.908, P=2.092 \times 10^{-30}\right), \mathrm{K}_{\mathrm{m}}$ and $\mathrm{V}_{\text {max-LT }}\left(\mathrm{r}=0.751, P=2.285 \times 10^{-15}\right)$, and $\mathrm{K}_{\mathrm{m}}$ and $\mathrm{V}_{\max -\mathrm{L}}$ $\left(\mathrm{r}=0.751, P=1.024 \times 10^{-13}\right)$ for $* 1 / * 1$ individuals; however, no significant correlation was seen for $* 1 / * 4$ individuals.

CYP2A $6 * 9$. Consistent with $C Y P 2 A 6^{*} 1 B$, the effect of $C Y P 2 A 6^{*} 9$ on phenotypes was not as significant as with $C Y P 2 A 6 * 4$ (Fig. 5). Only subjects with $C Y P 2 A 6^{*} 1 / * 1$ wild type and $* 1 / * 9$ heterozygotes were taken into analysis,
A1

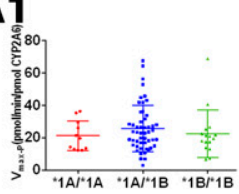

A2

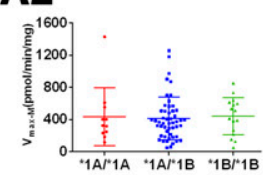

A3

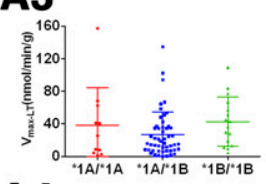

A4

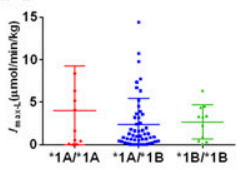

B1

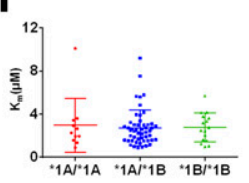

B2

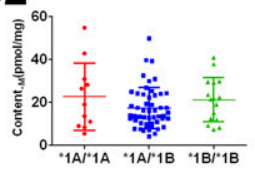

B3

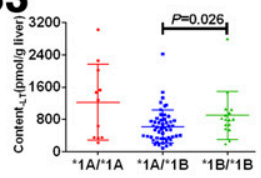

B4

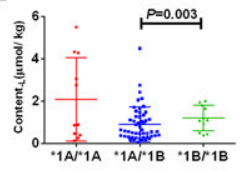

C1

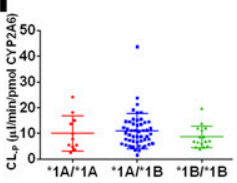

C2

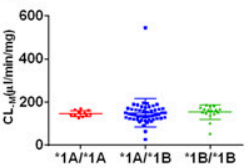

c3

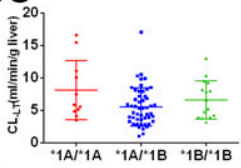

C4

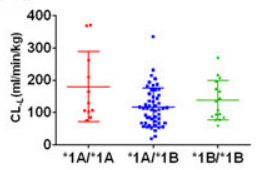

D1

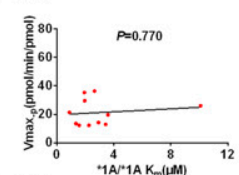

D2

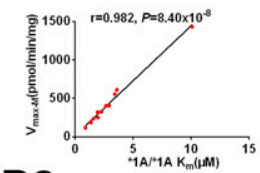

D3

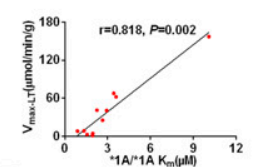

D4

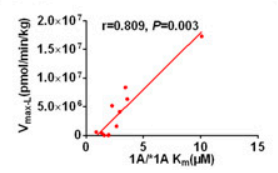

E1

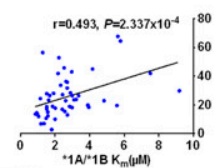

E2

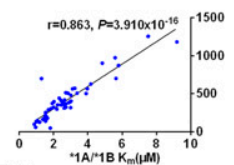

E3

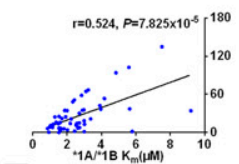

E4

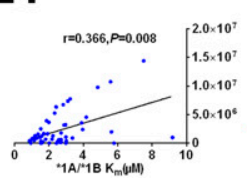

G1

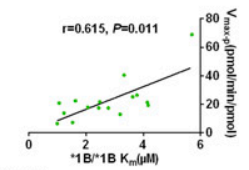

G2

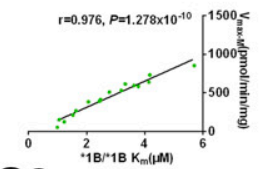

G3

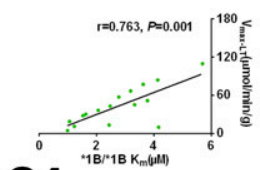

G4

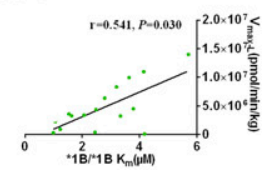

Fig. 3. Genotype-phenotype associations varied by CYP $2 A 6^{*} 1 B$ polymorphisms. A1 A4 $\left(\mathrm{V}_{\max -\mathrm{P}}, \mathrm{V}_{\max -\mathrm{M}}, \mathrm{V}_{\mathrm{max}-\mathrm{LT}}, \mathrm{V}_{\mathrm{max}-\mathrm{L})}\right.$, B1 B4 $\left(\mathrm{K}_{\mathrm{m}}, \mathrm{Content} \mathrm{M}_{-\mathrm{M}}\right.$ Content-LT , Content $-\mathrm{L}), \mathrm{C} 1 \sim \mathrm{C} 4\left(\mathrm{CL}_{-\mathrm{P}}, \mathrm{CL}_{-\mathrm{M}}, \mathrm{CL}_{-\mathrm{LT}}, \mathrm{CL}_{-\mathrm{L}}\right)$ were divided by ${ }^{*} 1 A / * 1 A, * 1 A / * 1 B$, and $* 1 B / * 1 B$ genotypes $(* 1 A / * 1 A, n=11 ; * 1 A / * 1 B$, $n=51 ; * 1 B / * 1 B, n=16)$. D1 D4, E1 E $4, \mathrm{G} 1 \sim \mathrm{G} 4$, correlation between $\mathrm{K}_{\mathrm{m}}$ with $\mathrm{V}_{\max -\mathrm{P}}, \mathrm{V}_{\max -\mathrm{M}}, \mathrm{V}_{\max -\mathrm{LT}}, \mathrm{V}_{\max -\mathrm{L}}$ in $* 1 \mathrm{~A} / * 1 \mathrm{~A}, * 1 \mathrm{~A} / * 1 \mathrm{~B}$ and $* 1 \mathrm{~B} / * 1 \mathrm{~B}$ genotypes, respectively. $V_{\text {max-P }}\left(\mathrm{pmol} / \mathrm{min}\right.$ per picomole), $\mathrm{CL}_{-\mathrm{P}}\left(\mu \mathrm{l} / \mathrm{min}\right.$ per picomole), the molecular phenotype or phenotype at the protein level. $\mathrm{V}_{\text {max-M }}$ (pmol/min per milligrams), $\mathrm{CL}_{-\mathrm{M}}\left(\mu \mathrm{l} / \mathrm{min}\right.$ per milligram), Content $-\mathrm{M}(\mathrm{pmol} / \mathrm{mg})$, the subcellular phenotype or phenotype at microsomal level. $\mathrm{V}_{\mathrm{max}-\mathrm{LT}}$ $\left(\mathrm{nmol} / \mathrm{min}\right.$ per gram), $\mathrm{CL}_{\text {-LT }}\left(\mathrm{ml} / \mathrm{min}\right.$ per gram), Content -LT $_{\mathrm{T}}(\mathrm{pmol} / \mathrm{g})$, the tissue phenotype or phenotype at liver tissue level. $\mathrm{V}_{\mathrm{max}-\mathrm{L}}(\mu \mathrm{mol} / \mathrm{min}$ per kilogram), $\mathrm{CL}_{-\mathrm{L}}\left(\mathrm{ml} / \mathrm{min}\right.$ per kilogram), Content $-\mathrm{L}(\mathrm{pmol} / \mathrm{kg})$, the organ phenotype or phenotype at liver level. $\mathrm{K}_{\mathrm{m}}(\mu \mathrm{M})$, the Michaelis-Menten constant. 
A1

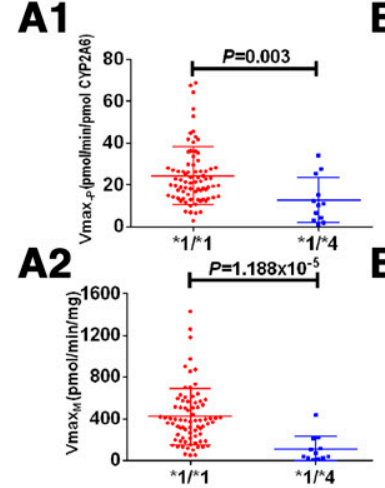

B1

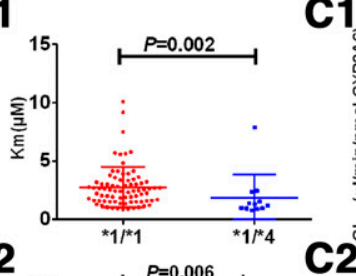

C1

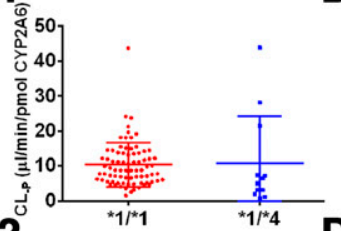

D1

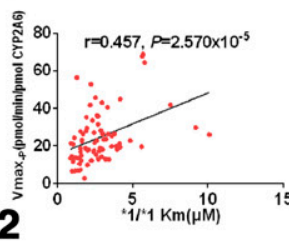

E1

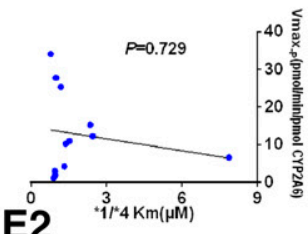

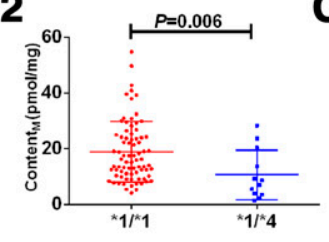

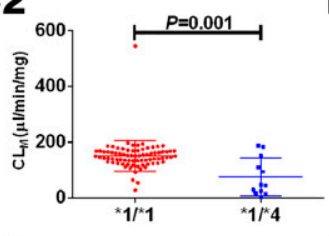

A3

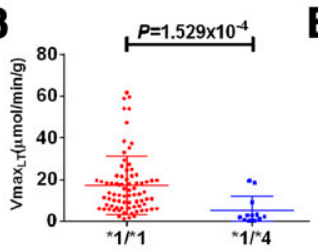

\section{B3}

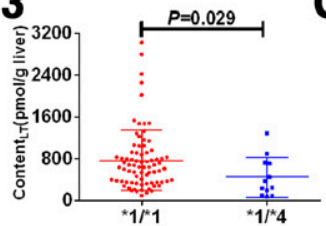

c3

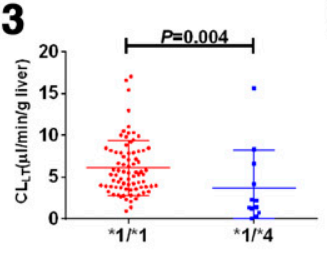

C4

A4

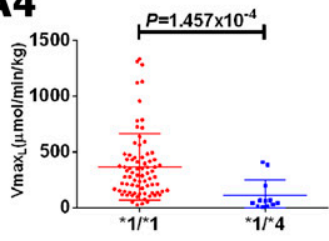

B4

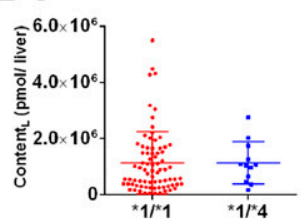

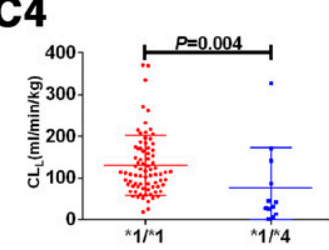

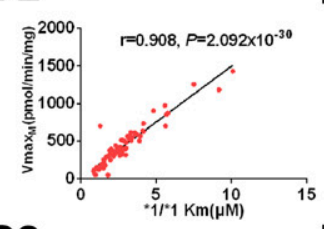

D3

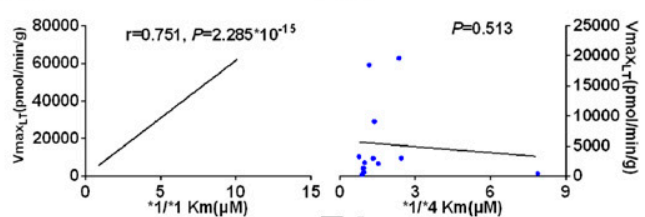

D4

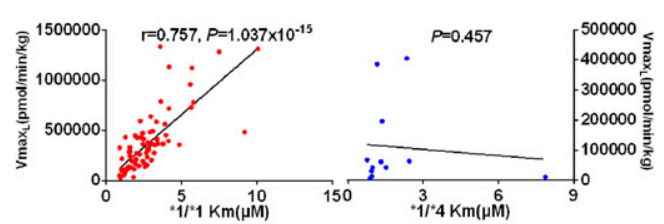

Fig. 4. Genotype-phenotype associations varied by CYP2A6*4 polymorphisms. A1 A4 $\left(\mathrm{V}_{\text {max-P }}, \mathrm{V}_{\text {max-M, }}, \mathrm{V}_{\text {max-LT, }}, \mathrm{V}_{\text {max- } \mathrm{L}}\right), \mathrm{B} 1 \sim \mathrm{B} 4\left(\mathrm{~K}_{\mathrm{m}}, \mathrm{Content}-\mathrm{M}\right.$, Content $_{-\mathrm{LT}}$, Content-L $), \mathrm{C} 1 \sim \mathrm{C} 4\left(\mathrm{CL}_{-\mathrm{P}}, \mathrm{CL}_{-\mathrm{M}}, \mathrm{CL}_{-\mathrm{LT}}, \mathrm{CL}_{-\mathrm{L}}\right)$ were divided by ${ }^{*} 1 /{ }^{*} 1$ and $* 1 / * 4$ genotypes $\left(* 1 / * 1, n=78 ;{ }^{*} 1 * 4, n=12\right)$. D1 D4, E1 E4, correlation between $\mathrm{K}_{\mathrm{m}}$ with $\mathrm{V}_{\text {max-P }}, \mathrm{V}_{\text {max-M}}, \mathrm{V}_{\text {max-LT, }} \mathrm{V}_{\text {max- } \mathrm{L}}$ in $* 1 / * 1$ and $* 1 / * 4$ genotypes, respectively. $\mathrm{V}_{\text {max-P }}\left(\mathrm{pmol} / \mathrm{min}\right.$ per picomole), CL $\mathrm{L}_{-\mathrm{P}}(\mu \mathrm{l} / \mathrm{min}$ per picomole), the molecular phenotype or phenotype at the protein level. $\mathrm{V}_{\text {max-M }}$ (pmol/min per milligram), CL $\mathrm{M}$ ( $\left.\mu \mathrm{l} / \mathrm{min} \mathrm{per} \mathrm{milligram}\right), \mathrm{Content}_{\mathrm{M}}$ (pmol/ $\mathrm{mg}$ ), the subcellular phenotype or phenotype at microsomal level. $\mathrm{V}_{\mathrm{max}-\mathrm{LT}}\left(\mathrm{nmol} / \mathrm{min}\right.$ per gram), $\mathrm{CL}_{-\mathrm{LT}}(\mathrm{ml} / \mathrm{min}$ per gram), Content $\mathrm{LT}$ ( $\mathrm{pmol} / \mathrm{g})$, the tissue phenotype or phenotype at liver tissue level. $\mathrm{V}_{\text {max-L }}\left(\mu \mathrm{mol} / \mathrm{min}\right.$ per kilogram), $\mathrm{CL}_{-\mathrm{L}}(\mathrm{ml} / \mathrm{min}$ per kilogram), Content $-\mathrm{L}(\mathrm{pmol} / \mathrm{kg})$, the organ phenotype or phenotype at liver level. $\mathrm{K}_{\mathrm{m}}(\mu \mathrm{M})$, the Michaelis-Menten constant.

without considering $* 9 / * 9$ homozygotes since only three individuals carried the $* 9 / * 9$ genotype. No significant difference was found in $\mathrm{V}_{\text {max-P }}$ for $* 1 / * 1$ carriers as compared with $* 1$ / $* 9$ carriers, and there was a dramatically lower $\mathrm{K}_{\mathrm{m}}$ for individuals with $* 1 / * 9(2.07 \mu \mathrm{M})$ than for ${ }^{*} 1 /{ }^{*} 1(3.03 \mu \mathrm{M})$ genotypes. The $\mathrm{CL}_{-\mathrm{P}}$ values, acquired by dividing individual $\mathrm{V}_{\text {max-P }}$ by each $\mathrm{K}_{\mathrm{m}}$ as described above, of $* 1 / * 9(12.72 \mu \mathrm{l} / \mathrm{min}$ per picomole) individuals seemed to be higher than $* 1 / * 1$ (8.71 $\mu \mathrm{l} / \mathrm{min}$ per picomole) subjects; however, this difference was not statistically significant. For both $\mathrm{V}_{\max -\mathrm{M}}$ and $\mathrm{V}_{\max -\mathrm{LT}},{ }^{*} 1 / * 9$ was associated with decreased activity as compared with wild type, which might be related to seemingly lower content ${ }_{-M}$ and

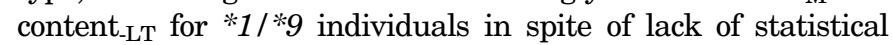
difference. Moreover, the $\mathrm{CL}_{-\mathrm{M}}$ for $2 A 6^{*} 1 / * 9$ was significantly lower than that of $* 1 / * 1$ individuals, which might be due to simultaneously lowered $\mathrm{V}_{\text {max-M }}$ and Content $-\mathrm{M}$ and a strongly significant association between $\mathrm{K}_{\mathrm{m}}$ and $\mathrm{V}_{\text {max-M}}$. For $\mathrm{V}_{\text {max-L}}$, Content $_{-\mathrm{LT}}$, Content $-\mathrm{L}, \mathrm{CL}_{-\mathrm{LT}}$, and $\mathrm{CL}_{-\mathrm{L}}$, no significant alteration was related with $* 9$ polymorphisms, even with a lower tendency of $\mathrm{V}_{\text {max-L }}$, Content $-\mathrm{LT}$, and Content $-\mathrm{L}$ for $* 1 / * 9$ individuals. We note that $\mathrm{K}_{\mathrm{m}}$ was strongly positively associated with $\mathrm{V}_{\max }$ within different levels for both CYP2A6*1/*1 and $C Y P 2 A 6^{*} 1 / * 9$ genotypes except for $\mathrm{V}_{\text {max-P }}$ in $C Y P 2 A 6^{*} 9$ wild-type carriers.

\section{Intergenotype Variation}

Intergenotype individual variations of CYP2A6 phenotypes at different levels were charted, and significant differences in variability among genetically different individuals are presented as seen in Fig. 6. Generally speaking, the $C Y P 2 A 6^{*} 4$ polymorphism led to the most remarkable alteration, with decreased $\mathrm{V}_{\max }$, Content, and CL at the majority of levels, whereas $C Y P 2 A 6^{*} 1 B$ and $* 9$ led to less obvious alteration either with increased or decreased phenotypes at some levels. Compared with wild type, various phenotypes including $\mathrm{V}_{\text {max-P, }}$, $\mathrm{V}_{\text {max-M}}, \mathrm{V}_{\text {max-LT }}, \mathrm{V}_{\text {max-L }}$, Content-M, Content-LT, CL-M, CL-LT, $\mathrm{CL}_{-\mathrm{L}}$, and $\mathrm{CL}_{-\mathrm{H}}$ of $* 1 / * 4$ showed an approximate decrease of $51 \%, 85 \%, 80 \%, 88 \%, 51 \%, 51 \%, 71 \%, 59 \%, 62 \%$, and $57 \%$, respectively, whereas the Content-L and $\mathrm{CL}_{-\mathrm{P}}$ were basically unchanged. For $C Y P 2 A 6^{*} 1 B$, Content $-\mathrm{LT}$, Content -L $_{\mathrm{L}}, \mathrm{CL}_{-\mathrm{LT}}$, $\mathrm{CL}_{-\mathrm{L}}$, and $\mathrm{CL}_{-\mathrm{H}}$ of mutant homozygotes were significantly higher than that of heterozygotes, whereas heterozygotes and mutant homozygotes were basically unchanged when compared with wild type. Most notably, $C Y P 2 A 6^{*} 1 B$ led to distinctly increased Content - $_{\mathrm{L}}$ with heterozygotes and mutant homozygotes showing 2.80-fold and 6.87-fold increases as compared with wild type, respectively. However, $\mathrm{CL}_{-\mathrm{L}}$ did not confirm this trend of change. With regard to $C Y P 2 A 6^{*} 9$, lowered $\mathrm{V}_{\text {max-P }}, \mathrm{V}_{\text {max-M}}, \mathrm{V}_{\text {max-LT }}$, Content-L, and $\mathrm{CL}_{-\mathrm{L}}$ of mutant heterozygotes were detected when compared with wild type, whereas Content ${ }_{-\mathrm{M}}, \mathrm{CL}_{-\mathrm{P}}$, and $\mathrm{CL}_{-\mathrm{M}}$ showed a reverse trend.

Moreover, with regard to $\mathrm{K}_{\mathrm{m}}$, in line with other phenotypes, the most remarkable alteration was with $* 1 / * 4$ genotypes, which showed a $49 \%$ reduction, whereas $* 9$ polymorphisms led 
A1

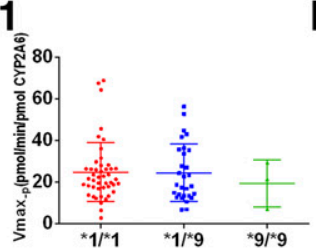

A2

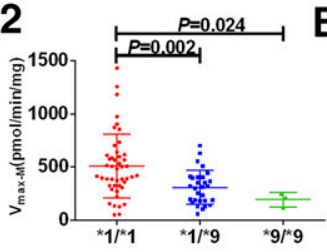

B1

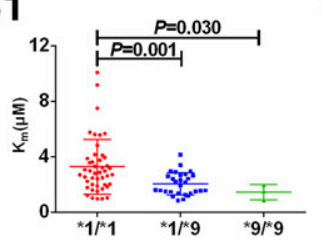

C1

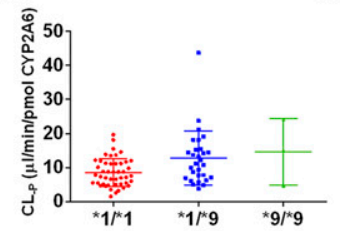

B2

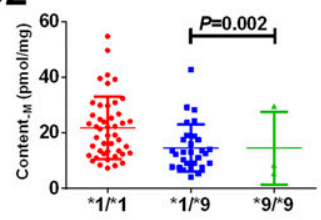

C2

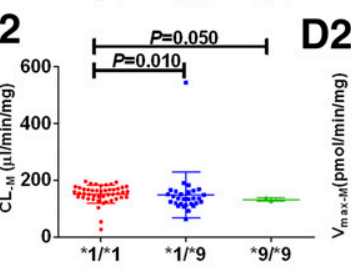

C3

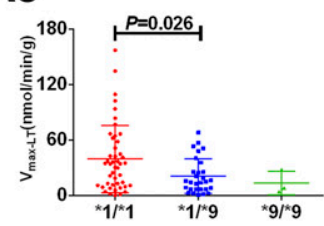

B3

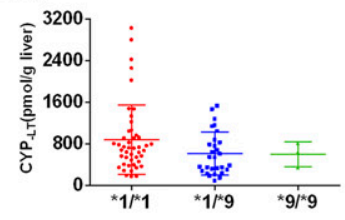

A4

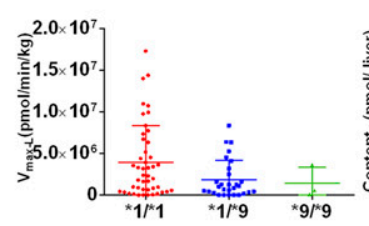

B4

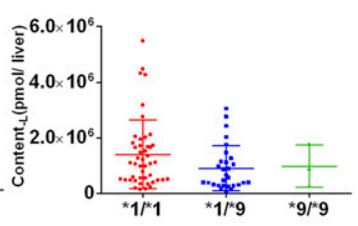

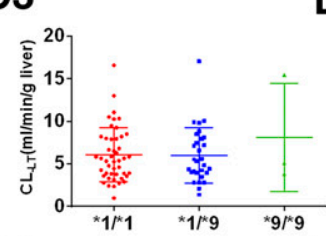

C4

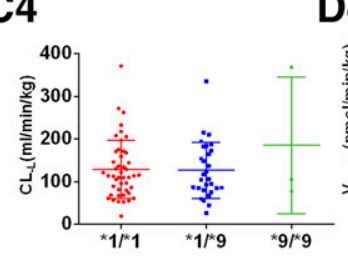

D1

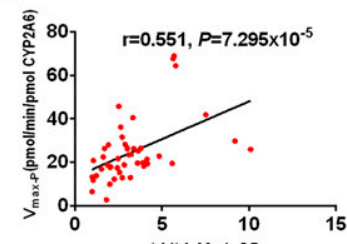

D2

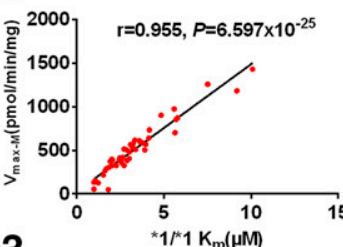

E1

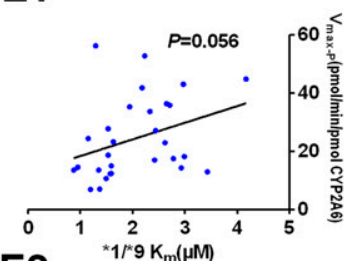

E2

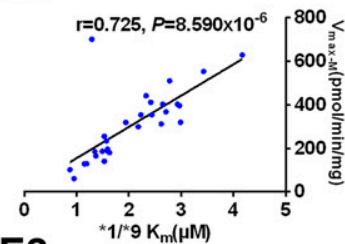

E3
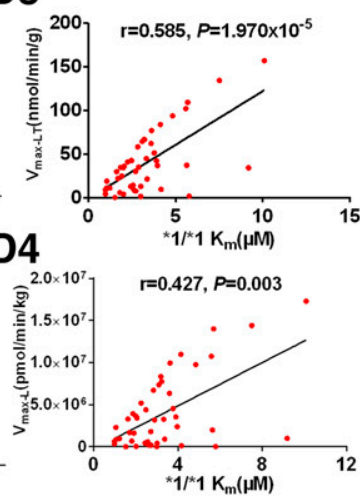

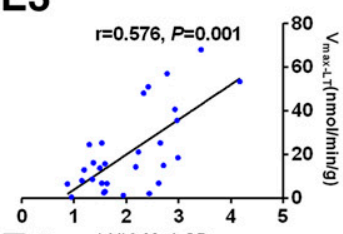

E4

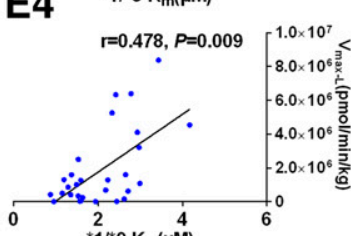

Fig. 5. Genotype-phenotype associations varied by $C Y P 2 A 6 * 9$ polymorphisms. A1 A4 $\left(\mathrm{V}_{\max -\mathrm{P}}, \mathrm{V}_{\mathrm{max}-\mathrm{M}}, \mathrm{V}_{\max -\mathrm{LT}}, \mathrm{V}_{\max -\mathrm{L})}, \mathrm{B} 1 \sim \mathrm{B} 4\left(\mathrm{~K}_{\mathrm{m}}, \mathrm{Content}-\mathrm{M}, \mathrm{Content}\right.\right.$-LT , Content-L), C1 C4 (CL -P $_{-}, \mathrm{CL}_{-\mathrm{M}}, \mathrm{CL}_{-\mathrm{LT}}$, and $\left.\mathrm{CL}_{-\mathrm{L}}\right)$ were divided by $* 1 / * 1, * 1 / * 9$, and $* 9 / * 9$ genotypes $(* 1 / * 1, n=46 ; * 1 / * 9, n=29 ; * 9 / * 9, n=3)$. D1 D4,

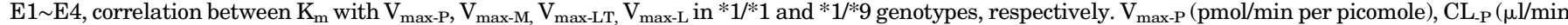
per picomole), the molecular phenotype or phenotype at the protein level. $\mathrm{V}_{\max -\mathrm{M}}\left(\mathrm{pmol} / \mathrm{min}\right.$ per milligram), $\mathrm{CL}_{-\mathrm{M}}\left(\mu \mathrm{l} / \mathrm{min}_{\mathrm{per}} \mathrm{milligram}\right), \mathrm{Content}_{-\mathrm{M}}$ (pmol/mg), the subcellular phenotype or phenotype at microsomal level. $\mathrm{V}_{\text {max-LT }}\left(\mathrm{nmol} / \mathrm{min}\right.$ per gram), $\mathrm{CL}_{\text {-LT }}(\mathrm{ml} / \mathrm{min} \mathrm{per} \mathrm{gram),} \mathrm{Content-LT}(\mathrm{pmol} / \mathrm{g})$, the tissue phenotype or phenotype at the liver tissue level. $\mathrm{V}_{\max -\mathrm{L}}\left(\mu \mathrm{mol} / \mathrm{min}\right.$ per kilogram), $\mathrm{CL}_{-\mathrm{L}}\left(\mathrm{ml} / \mathrm{min}\right.$ per kilogram), Content ${ }_{-\mathrm{L}}(\mathrm{pmol} / \mathrm{kg})$, the organ phenotype or phenotype at liver level. $\mathrm{K}_{\mathrm{m}}(\mu \mathrm{M})$, the Michaelis-Menten constant.

to distinctly lower $\mathrm{K}_{\mathrm{m}}$, with heterozygotes and mutant homozygotes showing $32 \%$ and $47 \%$ decreases as compared with wild type, respectively. For $C Y P 2 A 6^{*} 1 B, \mathrm{~K}_{\mathrm{m}}$ of $* 1 B$ carriers was basically unchanged for heterozygotes and homozygotes.

\section{Discussion}

In this present study of 90 human liver samples, the systematic delineation of a CYP2A6 genotype-phenotype model including protein content and metabolic activity of CYP2A6 at various levels such as molecular, cellular (microsomal, tissue, organ), and organismal levels was generated. We determined the median and range for the protein content, $\mathrm{V}_{\text {max }}$, and CL as well as relative phenotypes $\left(\mathrm{R}_{\text {-Content }}, \mathrm{R}_{\text {-Vmax }}\right.$, and $\mathrm{R}_{-\mathrm{CL}}$ ) at each level with every CYP2A6 genotype to elucidate how different $C Y P 2 A 6$ genotypes yield phenotypic traits (protein content and enzyme activity) at different levels. The high relative ICVs of phenotypes indicate large intraindividual variation within different levels, sometimes in a genotype-dependent manner. Intergenotype analysis indicated that $C Y P 2 A 6^{*} 4$ had the most obvious effect on phenotypes, and protein content might be related to the CYP2A $6 * 4$ allele. The correlation of phenotypes from the molecular level to the cellular level and then to the organismal level demonstrates how genotypes may affect phenotypes and could be considered for better understanding of phenotypic variation and assessment of phenotypic outcome with specific genotypes.

We did find that the alteration of phenotypes from the molecular level to the cellular level and then to organismal level varied greatly, which agrees with our previous studies (Zhang et al., 2015b; Gao et al., 2017a). However, our previous study on the CYP2D6 genotype-phenotype association (Gao et al., 2017a) indicated the effect of the CYP2D6 genotype on the metabolic phenotype at each level but did not consider the alteration of phenotypes among different levels. In this study, the ICVs of R-Vmax, $R_{-C L}$, and $R_{-}$-ontent within different levels indicated noticeable intraindividual variation and varied with the $C Y P 2 A 6$ genotype. Take the $C Y P 2 A 6^{*} 4$ allele, for example; the ICVs of $\mathrm{R}_{\text {-CL }}$ for CYP2A6*1/*4, 41.6\% (11.1\%-133.5\%), was nearly 1.56 -fold of that for the $* 1 / * 1$ genotype, $26.7 \%(2.39 \%-102.9 \%)$, whereas for $\mathrm{R}$-Vmax , the difference was 1.28 -fold. The reason for these differences might be the superimposed effect of genotype on phenotype since the effect on the molecular level might influence the cellular level and then the organismal level. In line with this speculation, the effect on CL might be the combined effect on $\mathrm{V}_{\max }$ and $\mathrm{K}_{\mathrm{m}}$ since CL was obtained by dividing $\mathrm{V}_{\max }$ by $\mathrm{K}_{\mathrm{m}}$. However, the precise mechanism underlying this needs further exploration.

The most impactful genotype-on-phenotype effect was with CYP2A6*4, which is a gene-deletion genotype, in contrast to 
A1

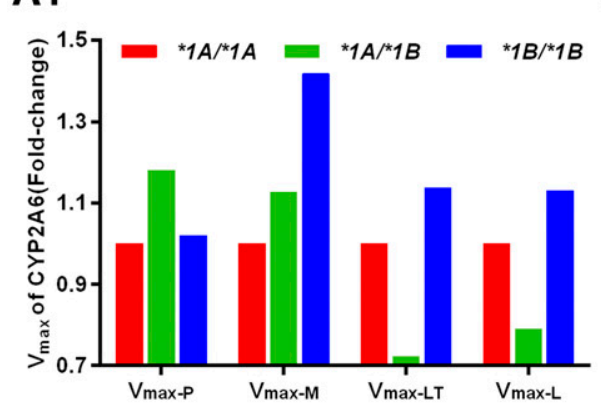

A2

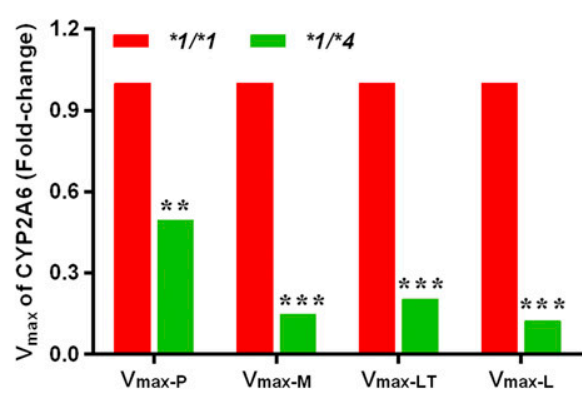

A3

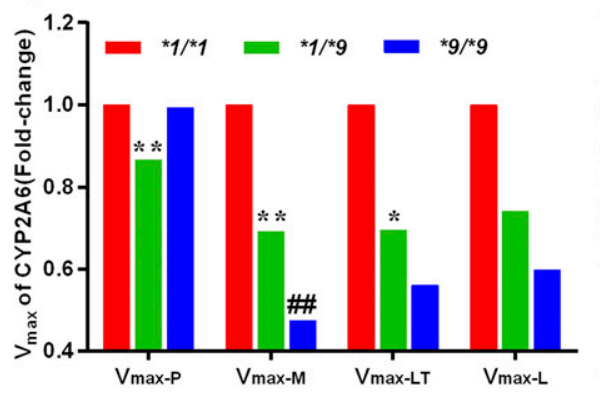

B1

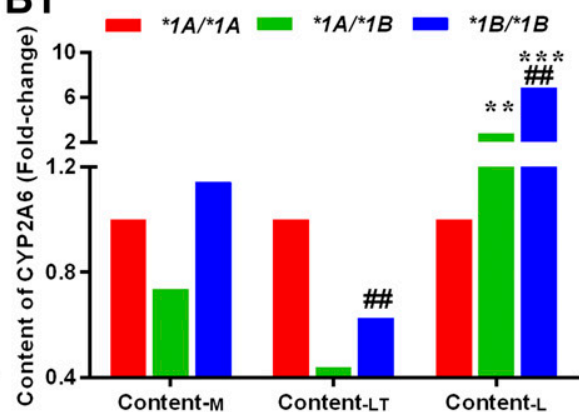

B2

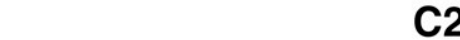

C1

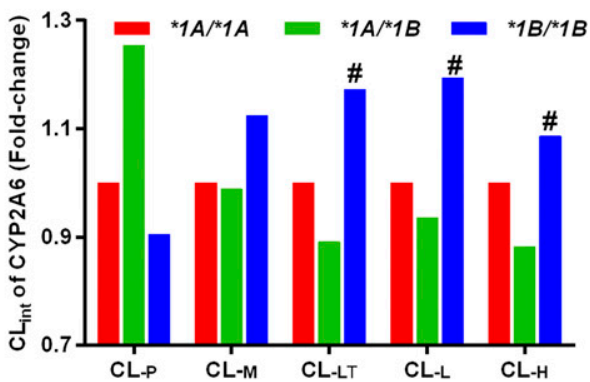

C2

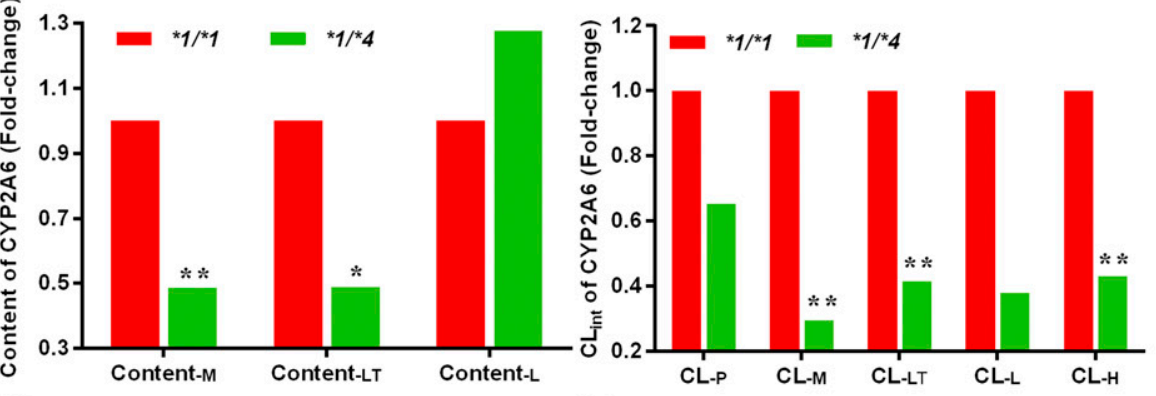

B3

\section{C3}
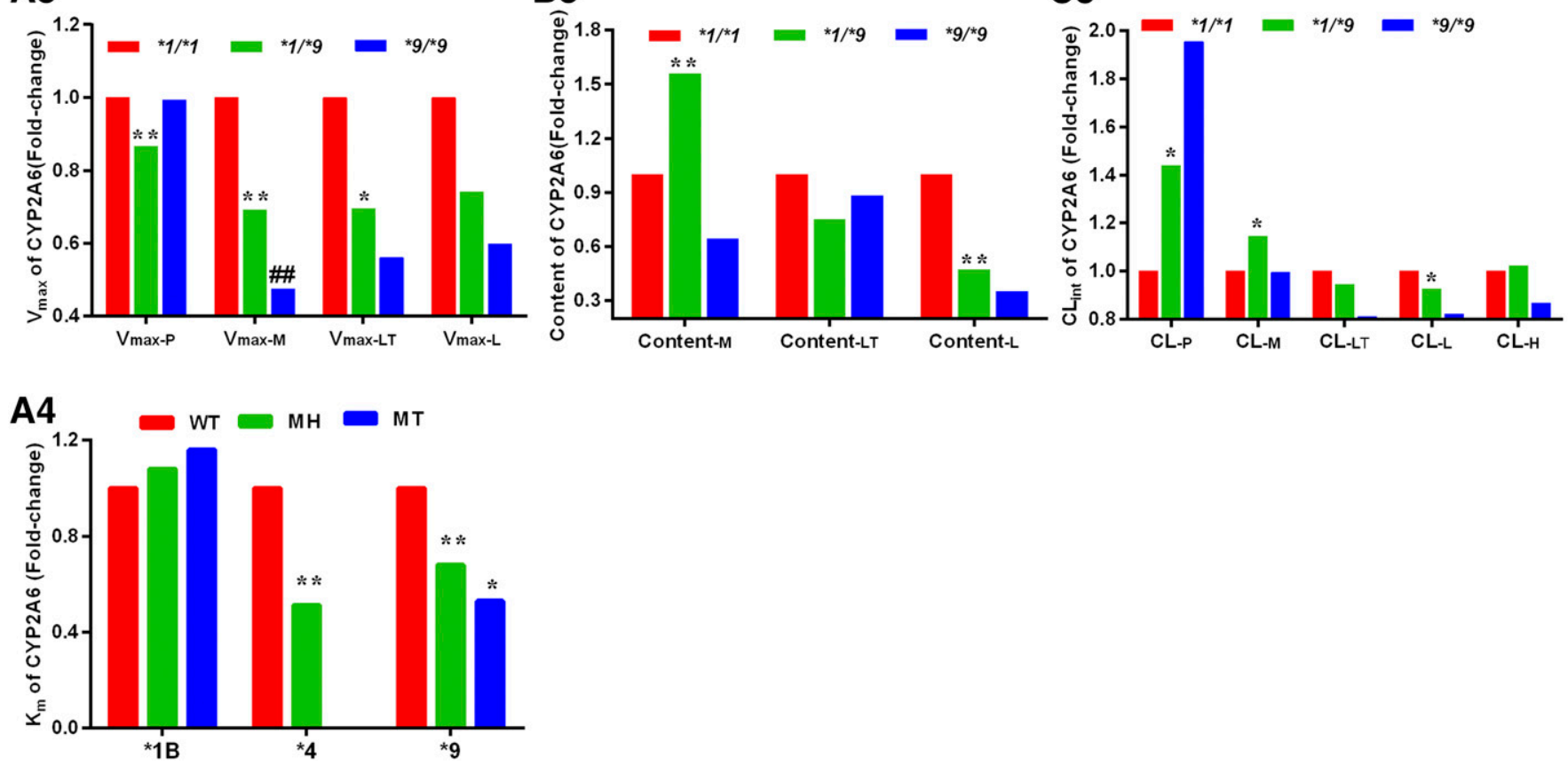

Fig. 6. The diversity in CYP2A6 phenotypes at different levels. A1 A3 (fold changes of $V_{\text {max-P }}, V_{\text {max-M }}, V_{\text {max-LT }}, V_{\text {max-L) }}$ ), $A 4$ (fold changes of $K_{m}$ ), B1 B3 (fold changes of Content-M, Content $-\mathrm{LT}$, Content -L $_{\mathrm{L}}$, C1 C3 (fold changes of CL $\mathrm{L}_{-\mathrm{P}}, \mathrm{CL}_{-\mathrm{M}}, \mathrm{CL}_{-\mathrm{LT}}, \mathrm{CL}_{-\mathrm{L}}, \mathrm{CL}_{-\mathrm{H}}$ ) were sorted by different CYP2A6 genotypes. As compared with wild type, fold changes of other genotypes were calculated by dividing the absolute value of the median for the phenotype by the absolute value of median for the corresponding wild type. The fold change for all phenotypes with wild type were defined as one. $C Y P 2 A 6^{*} 1 B(* 1 A / * 1 A, n=11$; $\left.{ }^{*} 1 A / * 1 B, n=51 ; * 1 B / * 1 B, n=16\right) ; C Y P 2 A 6 * 4(* 1 / * 1, n=78 ; * 1 * 4, n=12) ; C Y P 2 A 6 * 9(* 1 / * 1, n=46 ; * 1 / * 9, n=29 ; * 9 / * 9, n=3) . * P<0.05$, ${ }^{* *} P<0.01$, ***P $<0.001$ vs. wild type; ${ }^{\#} P<0.05$, ${ }^{\# \#} P<0.01$ vs. mutant heterozygotes.

the $* 1 \mathrm{~B}$ genotype (located in $3^{\prime}$ untranslated region) and the *9 mutation (located in the "TATA box"), being the least impactful phenotype as measured herein. Results are in agreement with a series of previous studies (Ujjin et al., 2002; Yoshida et al., 2003; Wang et al., 2006, 2011; Tanner et al., 2017), though those studies were conducted either in vitro by site-directed mutagenesis or in vivo by phenotyping using substrates. The location and type of mutation is clearly important when evaluating the phenotypic impact of different genotypes.

It is noteworthy that protein content might play an important role for extrapolation from the genotype of CYP2A6 to the different levels of phenotypes, especially for CYP $2 A 6^{*} 4$. $C Y P 2 A 6^{*} 4$, a coding-deletion genotype, was associated with significant decreased protein and acitvity in our study and also with the same effect in previous reports (Peamkrasatam 
et al., 2006; Wang et al., 2011). However, one such trend was detected in one study demonstrating protein content correlated well with activity (Tanner et al., 2017). The reason for the inconsistencies might be that liver samples conducted in that study were from two liver banks with different ethnicities, and only one $C Y P 2 A 6^{*} 1 / * 4$ sample was identified, and so the effect of the $C Y P 2 A 6^{*} 4$ genotype on phenotype could not be well evaluated. Our study focused on known but less common polymorphisms that were present at higher levels in the Chinese population. As depicted in Fig. 4, the markedly lower Content $-\mathrm{M}(10.62 \mathrm{pmol} / \mathrm{mg})$ and Content -LT $(3.70 \mathrm{ml} / \mathrm{min}$ per gram) in $* 1 / * 4$ genotypes might help explain the much greater decrease in $\mathrm{V}_{\text {max-M }}, \mathrm{V}_{\text {max-LT }}$, and $\mathrm{V}_{\text {max-L }}$ compared with $\mathrm{V}_{\text {max-P }}$ correlated with $C Y P 2 A 6^{*} 4$. This was consistent with the view that protein content and activity might play a role in determining metabolic phenotypes and susceptibility to disease (Tian et al., 2016; Gao et al., 2018a,b,c).

Most notably, one interesting finding was the highly significant positive correlation between $\mathrm{K}_{\mathrm{m}}$ and $\mathrm{V}_{\max }$ at each level in the*1/*1 wild type. Given that, we speculate that the significantly lowered $\mathrm{CL}_{-\mathrm{M}}, \mathrm{CL}_{-\mathrm{LT}}$, and $\mathrm{CL}_{-\mathrm{L}}$ in $*_{4}$ carriers might be due to the more prominent decreased $\mathrm{V}_{\max }$ when compared with $\mathrm{K}_{\mathrm{m}}$ at each corresponding level, whereas for the phenotype at the molecular level, the almost uniform extent of change for $V_{\text {max-P }}$ and $K_{m}$ might be the reason for the insignificant alteration of $\mathrm{CL}_{-\mathrm{P}}$ related to the $* 4$ variation. However, the explicit mechanism underlying this remains unknown and needs further investigation.

The interindividual variation of CYP2A6 phenotypes in relation to different genotypes at various levels may play a role in interethnic or interindividual variability for CYP2A6 phenotypes and the risk for CYP2A6-related disease. $C Y P 2 A 6^{*} 4$, in particular, correlated with lower $2 \mathrm{~A} 6$ phenotypes at a number of levels. For example, the median values of $\mathrm{V}_{\text {max-M }}$, Content $-\mathrm{M}$, and $\mathrm{CL}_{-\mathrm{M}}$ were decreased to $15 \%, 49 \%$, and $29 \%$, respectively, in *4 carriers when compared with $* 1$ wildtype carriers. This likely contributes to the known slower cotinine metabolism in Chinese-Americans than Caucasians (Benowitz et al., 2002) since the frequency of $C Y P 2 A 6^{*} 4$ in Chinese was 6.6\% 15.1\%, much higher than the Caucasian level of $0.5 \% \sim 4.9 \%$ (Xu et al., 2002).

The interethnic as well as interindividual variation in metabolic phenotypes might have several important clinical implications; for instance, CYP2A6-related metabolic activity (e.g., nicotine metabolism), behaviors (Malaiyandi et al., 2006; Gao et al., 2016a) (i.e., smoking), and disease (Fujieda et al., 2004) (i.e., lung cancer). Genetic studies on CYP2A6 in Japanese indicated a decreased rate of lung cancer in inactive CYP2A6 variants carriers in comparison with wild type (Miyamoto et al., 1999). In addition to the cigarette smoking-related lung cancer, CYP2A6 is also involved in the metabolism of many other procarcinogens. However, a clearer understanding of the role for genotypes of CYP2A 6 in relation to disease is needed before conclusions can be reached.

Since liver samples of perfectly healthy persons with comprehensive background information are difficult to obtain, the liver samples used here were from patients undergoing hepatic surgery. However, the donors were with clear medical diagnoses mostly of cavernous hemangioma of liver and mitigated by techniques and confirmed by analysis (Supplemental Fig. 5) to minimize impact of tumors and other demographic factors (Supplemental Figs. 1-4). Moreover, the total of 90 samples studied here with comprehensive background information is a large number of human samplings and is certainly adequate. Even so, high variability existed along with relatively low numbers per grouping and might still affect the ability to differentiate smaller differences. Many more samples are needed to rule out idiosyncratic variation as much as possible. Since it was not easy to simultaneously obtain in vivo and in vitro results for the same cohort of samples, no actual in vivo measurements were made in our study. We used in vitro measurements at different levels to predict hepatic clearance by in vitro-in vivo extrapolation to the in vivo level. After correction, our in vivo extrapolation by calculation yielded high accuracy, as indicated by the predicted CL of CYP2A6 matching $82.8 \%$ of the cases within 2-fold error when compared with actual observed $\mathrm{CL}_{\text {in vivo }}$ determined in other studies (Ritschel et al., 1977)(Gao et al., 2016a). Even so, actual in vivo measurements are additional efforts needed to draw more clear and convincing conclusions.

In conclusion, we have developed a comprehensive CYP2A6 genotype-to-phenotype model. In this model, a role for the CYP2A6 genotypes in influencing phenotypic variation at various levels was evaluated, although clearly it may not be sufficient to explain variation in all phenotypic outcomes. It does provide the basal data for CYP2A6 content and metabolic activities at different levels with each CYP2A6 genotype as well as fundamental hierarchical relationships between CYP2A6 genotypes and phenotypes. We identified a key role for decreased protein content for the $C Y P 2 A 6^{*} 4$ genotype that is related to decreased metabolic phenotypes. These findings might help open new approaches for considering how genetic variation is translated to the phenotype of individuals, which might be a further step on the way to making useful predictions of outcomes for a particular individual as a part of personalized medicine and disease risk.

\section{Acknowledgments}

The authors would like to thank professor Song-He Shi and XueZhong Shi for their valuable suggestions during the statistical analysis of data for this manuscript.

\section{Authorship Contributions}

Participated in research design: Qiao.

Conducted experiments: Fang, Wang.

Contributed new reagents or analytic tools: Guo, Zhang, Wen.

Performed data analysis: Fang, Wang.

Wrote or contributed to the writing of the manuscript: Fang, Xing, Gao, Qiao.

\section{References}

Barter ZE, Tucker GT, and Rowland-Yeo K (2013) Differences in cytochrome p450mediated pharmacokinetics between Chinese and Caucasian populations predicted by mechanistic physiologically based pharmacokinetic modelling. Clin Pharmacokinet 52:1085-1100.

Benowitz NL, Pérez-Stable EJ, Herrera B, and Jacob P III (2002) Slower metabolism and reduced intake of nicotine from cigarette smoking in Chinese-Americans. J Natl Cancer Inst 94:108-115.

Bradford MM (1976) A rapid and sensitive method for the quantitation of microgram quantities of protein utilizing the principle of protein-dye binding. Anal Biochem 72:248-254.

Dai DP, Xu RA, Hu LM, Wang SH, Geng PW, Yang JF, Yang LP, Qian JC, Wang ZS, Zhu GH, et al. (2014) CYP2C9 polymorphism analysis in Han Chinese populations: building the largest allele frequency database. Pharmacogenomics $J$ 14:85-92.

Fang Y, Gao J, Wang T, Tian X, Gao N, Zhou J, Zhang HF, Wen Q, Jin H, Xing YR, et al. (2018a) Intraindividual variation and correlation of cytochrome P450 activities in human liver microsomes. Mol Pharm 15:5312-5318.

Fang Y, Gao N, Tian X, Zhou J, Zhang HF, Gao J, He XP, Wen Q, Jia LJ, Jin H, et al. (2018b) Effect of P450 oxidoreductase polymorphisms on the metabolic activities of 
ten cytochrome P450s varied by polymorphic CYP genotypes in human liver microsomes. Cell Physiol Biochem 47:1604-1616.

Fujieda M, Yamazaki H, Saito T, Kiyotani K, Gyamfi MA, Sakurai M, Dosaka-Akita H, Sawamura Y, Yokota J, Kunitoh H, et al. (2004) Evaluation of CYP2A6 genetic polymorphisms as determinants of smoking behavior and tobacco-related lung cancer risk in male Japanese smokers. Carcinogenesis 25:2451-2458.

Fukami T, Nakajima M, Higashi E, Yamanaka H, Sakai H, McLeod HL, and Yokoi T (2005) Characterization of novel CYP2A6 polymorphic alleles (CYP2A6*18 and CYP2A6*19) that affect enzymatic activity. Drug Metab Dispos 33:1202-1210.

Gao J, Tian X, Zhou J, Cui MZ, Zhang HF, Gao N, Wen Q, and Qiao HL (2017a) From genotype to phenotype: cytochrome P450 2D6-mediated drug clearance in humans. Mol Pharm 14:649-657.

Gao J, Wang GJ, Wang Z, Gao N, Li J, Zhang YF, Zhou J, Zhang HX, Wen Q, Jin H et al. (2017b) High CYP2E1 activity correlates with hepatofibrogenesis induced by nitrosamines. Oncotarget 8:112199-112210.

Gao J, Wang J, Gao N, Tian X, Zhou J, Fang Y, Zhang HF, Wen Q, Jia LJ, Zou D, et al. (2017c) Prediction of cytochrome P450-mediated drug clearance in humans based on the measured activities of selected CYPs. Biosci Rep 37:1-13.

Gao J, Wang Z, Wang GJ, Gao N, Li J, Zhang YF, Zhou J, Zhang HX, Wen Q, Jin H, et al. (2018a) From hepatofibrosis to hepatocarcinogenesis: higher cytochrome $\mathrm{P} 450$ 2E1 activity is a potential risk factor. Mol Carcinog 57:1371-1382.

Gao J, Wang Z, Wang GJ, Zhang HX, Gao N, Wang J, Wang CE, Chang Z, Fang Y, Zhang YF, et al. (2018b) Higher CYP2E1 activity correlates with hepatocarcinogenesis induced by diethylnitrosamine. J Pharmacol Exp Ther 365:398-407.

Gao J, Zhou J, He XP, Zhang YF, Gao N, Tian X, Fang Y, Wen Q, Jia LJ, Jin H, et al. (2016a) Changes in cytochrome P450s-mediated drug clearance in patients with hepatocellular carcinoma in vitro and in vivo: a bottom-up approach. Oncotarget 7 : $28612-28623$.

Gao N, Li J, Li MR, Qi B, Wang Z, Wang GJ, Gao J, and Qiao HL (2018c) Higher activity of alcohol dehydrogenase is correlated with hepatic fibrogenesis. J Pharmacol Exp Ther 367:473-482.

Gao N, Tian X, Fang Y, Zhou J, Zhang H, Wen Q, Jia L, Gao J, Sun B, Wei J, et al. (2016b) Gene polymorphisms and contents of cytochrome P450s have only limited effects on metabolic activities in human liver microsomes. Eur J Pharm Sci 92 86-97.

Li J, Zhou L, Wang H, Yan H, Li N, Zhai R, Jiao F, Hao F, Jin Z, Tian F, et al. (2015) A new sample preparation method for the absolute quantitation of a target proteome using (18)O labeling combined with multiple reaction monitoring mass spectrometry. Analyst (Lond) 140:1281-1290.

Malaiyandi V, Lerman C, Benowitz NL, Jepson C, Patterson F, and Tyndale RF (2006) Impact of CYP2A6 genotype on pretreatment smoking behaviour and nicotine levels from and usage of nicotine replacement therapy. Mol Psychiatry 11: 400-409.

Mega JL, Close SL, Wiviott SD, Shen L, Hockett RD, Brandt JT, Walker JR, Antman EM, Macias W, Braunwald E, et al. (2009) Cytochrome p-450 polymorphisms and response to clopidogrel. $N$ Engl J Med 360:354-362.

Miyamoto M, Umetsu Y, Dosaka-Akita H, Sawamura Y, Yokota J, Kunitoh H, Nemoto N, Sato K, Ariyoshi N, and Kamataki T (1999) CYP2A6 gene deletion reduces susceptibility to lung cancer. Biochem Biophys Res Commun 261:658-660.

Mürdter TE, Kerb R, Turpeinen M, Schroth W, Ganchev B, Böhmer GM, Igel S, Schaeffeler E, Zanger U, Brauch H, et al. (2012) Genetic polymorphism of cytochrome P450 2D6 determines oestrogen receptor activity of the major infertility drug clomiphene via its active metabolites. Hum Mol Genet 21:1145-1154.

Oscarson M, McLellan RA, Gullstén H, Yue QY, Lang MA, Bernal ML, Sinues B, Hirvonen A, Raunio H, Pelkonen O, et al. (1999) Characterisation and PCR-based detection of a CYP2A6 gene deletion found at a high frequency in a Chinese population. FEBS Lett 448:105-110.

Palma BB, Silva E Sousa M, Vosmeer CR, Lastdrager J, Rueff J, Vermeulen NP, and Kranendonk M (2010) Functional characterization of eight human cytochrome P450 1A2 gene variants by recombinant protein expression. Pharmacogenomics $J$ 10:478-488

Peamkrasatam S, Sriwatanakul K, Kiyotani K, Fujieda M, Yamazaki H, Kamataki T, and Yoovathaworn K (2006) In vivo evaluation of coumarin and nicotine as probe drugs to predict the metabolic capacity of CYP2A6 due to genetic polymorphism in Thais. Drug Metab Pharmacokinet 21:475-484.

Ritschel WA, Brady ME, Tan HS, Hoffmann KA, Yiu IM, and Grummich KW (1977) Pharmacokinetics of coumarin and its 7-hydroxy-metabolites upon intravenous and peroral administration of coumarin in man. Eur J Clin Pharmacol 12:457-461.

Sadeque AJ, Fisher MB, Korzekwa KR, Gonzalez FJ, and Rettie AE (1997) Human CYP2C9 and CYP2A6 mediate formation of the hepatotoxin 4-ene-valproic acid. J Pharmacol Exp Ther 283:698-703.

Shuker N, Bouamar R, van Schaik RH, Clahsen-van Groningen MC, Damman J, Baan CC, van de Wetering J, Rowshani AT, Weimar W, van Gelder T, et al. (2016) A randomized controlled trial comparing the efficacy of Cyp3a5 genotype-based with body-weight-based tacrolimus dosing after living donor kidney transplantation. Am J Transplant 16:2085-2096.

Tanner JA, Prasad B, Claw KG, Stapleton P, Chaudhry A, Schuetz EG, Thummel $\mathrm{KE}$, and Tyndale RF (2017) Predictors of variation in CYP2A6 mRNA, protein, and enzyme activity in a human liver bank: influence of genetic and nongenetic factors. $J$ Pharmacol Exp Ther 360:129-139.

Tennessen JA, Bigham AW, O'Connor TD, Fu W, Kenny EE, Gravel S, McGee S, Do R, Liu X, Jun G, et al.; Broad GO; Seattle GO; NHLBI Exome Sequencing Project (2012) Evolution and functional impact of rare coding variation from deep sequencing of human exomes. Science 337:64-69.

Tian X, Li HM, Wei JY, Liu BJ, Zhang YH, Wang GJ, Chang JB, and Qiao HL (2016) Preclinical pharmacokinetics, tissue distribution, and plasma protein binding of sodium ( \pm )-5-bromo-2-( $\alpha$-hydroxypentyl) benzoate (BZP), an innovative potent anti-ischemic stroke agent. Front Pharmacol 7:255.

Ujiin P, Satarug S, Vanavanitkun Y, Daigo S, Ariyoshi N, Yamazaki H, Reilly PE, Moore MR, and Kamataki T (2002) Variation in coumarin 7-hydroxylase activity associated with genetic polymorphism of cytochrome P450 2A6 and the body status of iron stores in adult Thai males and females. Pharmacogenetics 12:241-249.

Wang H, Bian T, Liu D, Jin T, Chen Y, Lin A, and Chen C (2011) Association analysis of CYP2A6 genotypes and haplotypes with 5-fluorouracil formation from tegafur in human liver microsomes. Pharmacogenomics 12:481-492.

Wang J, Pitarque M, and Ingelman-Sundberg M (2006) 3'-UTR polymorphism in the human CYP2A6 gene affects mRNA stability and enzyme expression. Biochem Biophys Res Commun 340:491-497.

Wang XF, Li B, Lan X, Yuan D, Zhang M, Wei YG, Zeng Y, Wen TF, Zhao JC and Yan LN (2008) Establishment of formula predicting adult standard liver volume for liver transplantation. Zhonghua Wai Ke Za Zhi 46:1129-1132.

Werk AN and Cascorbi I (2014) Functional gene variants of CYP3A4. Clin Pharmacol Ther 96:340-348.

White IN, Razvi N, Gibbs AH, Davies AM, Manno M, Zaccaro C, De Matteis F, Pähler A, and Dekant W (2001) Neoantigen formation and clastogenic action of HCFC-123 and perchloroethylene in human MCL-5 cells. Toxicol Lett 124:129-138.

Xu C, Goodz S, Sellers EM, and Tyndale RF (2002) CYP2A6 genetic variation and potential consequences. Adv Drug Deliv Rev 54:1245-1256.

Yoshida R, Nakajima M, Nishimura K, Tokudome S, Kwon JT, and Yokoi T (2003) Effects of polymorphism in promoter region of human CYP2A6 gene (CYP2A6*9) on expression level of messenger ribonucleic acid and enzymatic activity in vivo and in vitro. Clin Pharmacol Ther 74:69-76.

Yuan D, Lu T, Wei YG, Li B, Yan LN, Zeng Y, Wen TF, and Zhao JC (2008) Estimation of standard liver volume for liver transplantation in the Chinese population. Transplant Proc 40:3536-3540.

Zanger UM and Schwab M (2013) Cytochrome P450 enzymes in drug metabolism: regulation of gene expression, enzyme activities, and impact of genetic variation. Pharmacol Ther 138:103-141.

Zhang H, Gao N, Liu T, Fang Y, Qi B, Wen Q, Zhou J, Jia L, and Qiao H (2015a) Effect of cytochrome b5 content on the activity of polymorphic CYP1A2, 2B6, and 2E1 in human liver microsomes. PLoS One 10:e128547.

Zhang H, Gao N, Tian X, Liu T, Fang Y, Zhou J, Wen Q, Xu B, Qi B, Gao J, et al. $(2015 \mathrm{~b})$ Content and activity of human liver microsomal protein and prediction of individual hepatic clearance in vivo. Sci Rep 5:17671.

Zhang HF, Wang HH, Gao N, Wei JY, Tian X, Zhao Y, Fang Y, Zhou J, Wen Q, Gao J, et al. (2016) Physiological content and intrinsic activities of 10 cytochrome P450 isoforms in human normal liver microsomes. J Pharmacol Exp Ther 358:83-93.

Zhou J, Wen Q, Li SF, Zhang YF, Gao N, Tian X, Fang Y, Gao J, Cui MZ, He XP, et al. (2016) Significant change of cytochrome P450s activities in patients with hepatocellular carcinoma. Oncotarget 7:50612-50623.

Zhu HJ, Yuan SH, Fang Y, Sun XZ, Kong H, and Ge WH (2011) The effect of CYP3A5 polymorphism on dose-adjusted cyclosporine concentration in renal transplant recipients: a meta-analysis. Pharmacogenomics $J$ 11:237-246.

Zordoky BN and El-Kadi AO (2010) Effect of cytochrome P450 polymorphism on arachidonic acid metabolism and their impact on cardiovascular diseases. Pharmacol Ther 125:446-463.

Address correspondence to: Hai-Ling Qiao, Institute of Clinical Pharmacology, Zhengzhou University, No 40, Daxue Road, Erqi District, Zhengzhou City 450052, Henan Province, China. E-mail: qiaohl@zzu.edu.cn; Na Gao, Institute of Clinical Pharmacology, Zhengzhou University, No 40, Daxue Road, Erqi District, Zhengzhou City 450052, Henan Province, China. E-mail: gaonawe@zzu.edu.cn; or Yu-Rong Xing, Center of Health Examination, The First Affiliated Hospital of Zhengzhou University, Zhengzhou 450052, Henan, China. E-mail: 405274775@qq.com 